\title{
ipen
}

AUTARQUIA ASSOCIADA À UNIVERSIDADE DE SÃO PAULO

\section{A IMPRENSA E A PERCEPÇÃO DE RISCOS NUCLEARES}

\section{CRISTIANE TEIXEIRA MANETTI}

Dissertação apresentada como parte dos requisitos para obtenção do Grau de Mestre em Ciências, na Área de Tecnologia Nuclear Aplicações.

Orientador:

Prof. Dr. Goro Hiromoto

SÃO PAULO 


\section{AGRADECIMENTOS}

Ao Dr. Goro Hiromoto pela orientação, confiança e incentivo no decorrer deste trabalho.

À Dra. Cilene Victor, pelo interesse constante, valiosas discussões e grandes contribuições.

Ao Dr. Carlos Celso do Amaral e Silva, pela iniciação na área de análise de risco.

Ao Instituto de Pesquisas Energéticas e Nucleares, pela oportunidade de realização deste trabalho.

A Deus.

Ao Fábio e o Lucas pela compreensão e apoio. 


\title{
A IMPRENSA E A PERCEPÇÃO DE RISCOS NUCLEARES
}

\author{
Cristiane Teixeira Manetti
}

\begin{abstract}
RESUMO
Neste trabalho foram identificadas a freqüência de pautas negativas e positivas sobre a questão nuclear na mídia impressa. A complexidade do tema é um fato, por isso, optamos por um estudo de caso que pudesse ilustrar a discussão teórica presente nesta pesquisa. Assim, pela presença constante na imprensa nacional e estrangeira, optamos, como estudo de caso, pela cobertura da imprensa sobre a energia nuclear após o lançamento do quarto relatório do IPCC, em fevereiro de 2007. O período da análise é de fevereiro de 2007, data de divulgação do relatório, até fevereiro de 2008, perfazendo um ano de estudo da cobertura jornalística. A pesquisa foi centrada nos veículos impressos, uma vez que há diferenças significativas entre as mídias impressa, televisiva, radiofônica e on-line que impedem o uso da mesma referência bibliográfica. Neste estudo foi coletado material jornalístico envolvendo a energia nuclear e verificou-se o discurso predominante dos veículos de comunicação e das fontes de informação. Notou-se uma predominância de reportagens positivas sobre o tema, devido principalmente ao peso do discurso favorável das autoridades, citadas com frequência neste estudo. É notório o enfoque quase sempre negativo assumido pelas ONGs em geral no trato desta questão. Também é importante salientar que todos os veículos de informação rastreados mesclaram reportagens positivas e negativas sobre o tema; e houve evidências de discurso hegemônico por parte das fontes oficiais.
\end{abstract}




\title{
THE PRESS MIDIA AND THE RISK PERCEPTION
}

\section{Cristiane Teixeira Manetti}

\begin{abstract}
In this study it was identified the frequency of negative and positive news on the nuclear question in the press media. Due to the complexity of the matter, we opt to perform a study case that could illustrate the theoretical discussion presented in this research. Thus, due to the constant presence of news related to IPCC meeting, in the national and foreign press, we opt to focus our study on one year period just after the release of the 4th IPCC Report, in February of 2007. The research was centered only in the printed matters, since there is significant differences between the printed media and others, like TV, radio or web, restricting the use of the same bibliographical reference. In this study it was collected journalistic material involving the nuclear energy and was verified the predominant speech of the vehicles of communication and the sources of information. It was noted the predominance of positive articles, mainly due to the weight of the favorable speeches by authorities, cited as the most frequent in the paper. The negative approach almost always was assumed by the ONGs in general, as expected, due to the its well known position in the treatment of matters related to the nuclear energy. Also it is important to point out that all the tracked vehicles of information mixed positive and negative news articles on the subject; and evidences of hegemonic speech by official sources had been observed.
\end{abstract}




\section{Página}

1. INTRODUÇÃO

1.1. Objetivos

2. A ENERGIA NUCLEAR NO CENÁRIO DO AQUECIMENTO GLOBAL

2.1. O IPCC

2.2. A Matriz Energética Brasileira

2.3. A Energia Nuclear

2.3.1. A Situação da Energia Nuclear no Brasil

3. O PAPEL DA IMPRENSA NA FORMAÇÃO DA PERCEPÇÃO DE RISCOS

3.1. A Percepção de Riscos Nucleares

3.2. O Papel Social da Prática Jornalística

3.3. O Discurso Jornalístico

3.4. A Construção do Real - Jornalismo e Divulgação Científica

3.5. Os Desafios da Imprensa Científica e Ambiental

4. A COBERTURA DA IMPRENSA SOBRE A QUESTÃO NUCLEAR EM 2007

4.1. Coleta de Material Jornalístico

4.2. Frequência das fontes de informação

4.3. Análise da Abordagem

4.4. Hegemonia das Fontes

80

4.5. O Discurso Hegemônico

5. CONCLUSÕES 


\section{LISTA DE TABELAS}

Tabela 1 - Geração de Energia elétrica no mundo (2006)

Tabela 2 -Número de centrais nucleares e potência instalada em 2007 no mundo

Tabela 3 - Energia nuclear: unidades e potência em construção em 2007

Tabela 4 - Usinas existentes suas potências e futuras instalações

Tabela 5 - Classificação das fontes de informação

Tabela 6 - Notícias envolvendo a energia nuclear 45

Tabela 7 - Número de matérias e discursos analisados por veículos de comunicação 74

Tabela 8 - Número de tipos de abordagem por veículo de comunicação 76

Tabela 9 - Número de tipos de abordagem por fonte de informação

Tabela 10 - Discurso hegemônico 


\section{LISTA DE FIGURA}

Figura 1 - Estrutura do Programa Nuclear Brasileiro 


\section{LISTA DE GRÁFICOS}

Gráfico 1 - Participação percentual das fontes para a geração de energia elétrica no Brasil

Gráfico 2 - As maiores reservas de urânio conhecidas no mundo

Gráfico 3 - Distribuição temporal das notícias ao longo do período estudado

Gráfico 4 - Frequência dos principais pontos citados na caracterização das abordagens 78 positivas

Gráfico 5 - Frequência dos principais pontos citados na caracterização das abordagens 79 negativas 


\section{INTRODUÇÃO}

Desde a divulgação do quarto relatório do IPCC (Painel Intergovernamental para Mudança do Clima), em fevereiro de 2007, as discussões sobre as mudanças climáticas ganharam visibilidade na imprensa nacional e estrangeira.

O IPCC nunca havia conseguido tanto destaque na imprensa; a principal razão foi o fato de o relatório do Grupo de Trabalho 1 (GT1), responsável pelo registro do atual quatro das mudanças climáticas, afirmar "é muito provável que o aquecimento global seja antropogênico, com chance acima de 90\%”.

Em outubro de 2006, o governo britânico divulgou um estudo realizado pelo economista Richard Stern sobre as previsões econômicas frente aos impactos das mudanças climáticas. O Relatório Stern, como ficou conhecido o documento, prevê perdas econômicas significativas se nada for feito para minimizar os danos decorrentes do aquecimento global.

Outro documento importante relacionado ao aquecimento global foi divulgado pela Agência de Energia Atômica Norte-Americana (AEA), em 2007. O relatório da AEA sugere o uso da energia nuclear como solução para combater o impacto dos gases do efeito estufa de matrizes energéticas a base de combustíveis fósseis.

Foi a partir desse cenário de estudos e discussões sobre os impactos do aquecimento global que a questão nuclear voltou a ocupar as páginas dos jornais brasileiros.

A sociedade tem convivido com agentes e situações de risco desencadeadas pelo desenvolvimento tecnológico e científico. A tecnologia nuclear exemplifica os riscos tecnológicos e suas abrangências, uma série de percepções favoráveis e desfavoráveis ao uso desta tecnologia é descrita por diversos segmentos da sociedade, devido aos acidentes do passado.

Percebe-se um crescente interesse e conscientização da população sobre riscos, juntamente com sua perda de confiança nos gerentes industriais e nas ações do governo, o que têm impulsionado uma postura crítica do público em geral frente à aceitação de riscos, em particular, aqueles introduzidos pela ação humana. 
Neste contexto, a avaliação de risco tem sido o processo utilizado para estimar a probabilidade de ocorrência de um evento e a provável magnitude dos efeitos adversos. Por outro lado, do ponto de vista social, as definições de risco assumem múltiplas dimensões, pois tendem a se basear em valores mais subjetivos como controle, confiabilidade e equidade, ou seja, são avaliadas em função da forma pela qual a sociedade percebe determinado risco (Hansson, 1989; Sandman, 1993; Lindell, 1996;.Nielsen, 1996).

Nos processos decisórios, no entanto, a avaliação de risco sempre foi considerada de domínio exclusivo da ciência, ou seja, baseada em avaliações quantitativas objetivas. Hoje, há um crescente questionamento do papel que a percepção de risco poderia ou deveria exercer neste contexto; cada vez mais, a reação do público aos riscos vem sendo discutida, tanto no contexto de adoção de políticas públicas, quanto de estratégias organizacionais (Cogliano, 1997; Slovic, 1996; Stallen, 1996; IAEA, 1994).

A preocupação do público com os riscos ambientais e tecnológicos, por exemplo, tem levado as agências governamentais a buscar mecanismos que possibilitem e assegurem o acesso adequado às informações sobre os riscos (Covello \& MacCallum, 1989).

Ao não assumir a responsabilidade de viabilizar o acesso da população às informações oficiais sobre os riscos, em especial, àquelas resultantes da avaliação dos riscos, as autoridades tendem a expor a sociedade aos efeitos dos diversos interesses escusos presentes no contexto do gerenciamento dos riscos.

Essa responsabilidade, por sua vez, acaba sendo transferida, ainda que involuntariamente, aos meios jornalísticos (jornal, revista, telejornal) e a outros grupos ou instituições, na sua maioria, com postura e posição predefinidas sobre determinado risco.

$\mathrm{Na}$ maioria das situações que envolvem um agente de risco, existe uma dificuldade de comunicação entre os especialistas em segurança e o público em geral. Isto se dá, principalmente, devido à diferença entre a forma como cada um dos grupos sociais concebe o risco. Diversas pesquisas nas áreas de percepção e comunicação de riscos têm apontado para aspectos ou características do risco que levam à formação da atitude ou percepção dos riscos por parte das pessoas leigas (Slovic, 1996; 1987. Sjöberg e DrottzSjöberg, 1994).

A forma tradicional como a indústria ou o governo trata a divergência de opiniões sobre os diversos tipos de risco consiste em assumir que o público está simplesmente errado e que a solução está em educá-lo, mostrando que os especialistas estão corretos. 
Entretanto, muitos estudos mostram que esta visão unidirecional da educação e comunicação de risco está equivocada (NSC, 1993; Garrick, 1991; Covello, 1985).

Reconhece-se hoje que a comunicação de risco não envolve apenas informação sobre risco, mas também a troca de percepções, opiniões e preferências entre uma série de atores sociais. A percepção do risco é tão importante quanto a realidade do risco; a sua aceitação é mais dependente da confiança do público no gerenciamento eficaz do risco do que em estimativas quantitativas.

A comunicação de riscos, portanto, não deve ser confundida como mera transmissão de informações, de dados científicos de um público especialista a um de não especialistas. Tal simplificação dá origem à interpretação equivocada de que, ao transmitir as informações, o dever foi cumprido - condição que nega a participação da população no processo de tomada de decisão.

Assim, comunicação de riscos apresenta-se como um processo que possibilita o acesso à informação e, ao mesmo tempo, o envolvimento do público interessado ou afetado com a temática.

Os estudos de comunicação, desde o início do século XX, com a chamada Escola de Chicago, demonstram a estreita relação entre comunicação e percepção (Mattelart, 1999). No contexto do gerenciamento de riscos, essa relação está cada vez mais estreita. Fenômenos culturais e comunicacionais têm influenciado diretamente a percepção de riscos e, conseqüentemente, impactado o gerenciamento do risco.

Para promover a discussão teórico-conceitual no presente trabalho, fez-se necessário, primeiramente, um levantamento bibliográfico que partisse dos principais autores do jornalismo, tais como Genro Filho, Marcondes Filho e José Marques de Melo, cujos estudos e pesquisas têm revelado dados preciosos sobre a história, a prática, as influências e a evolução do jornalismo.

Na visão de Michael Kunczik, o breve histórico do jornalismo no mundo mostra a necessidade de liberdade de imprensa, elemento fundamental para a arte de informar e disseminar notícias, e acrescenta, de modo especial, a responsabilidade do jornalista para com a sociedade. 
Essa preocupação vai ao encontro da relação entre a grande imprensa e o poder que, ao longo dos anos, vem criando uma forma quase que indissolúvel. As consequiências desse processo estimulam a falta de preocupação ambiental, apenas servindo como força política que identifica os jornais como um meio para defender seus objetivos.

Tal interesse passa pelos estudos da Escola de Frankfurt, que, ao analisar os efeitos da indústria cultural, deram uma importante contribuição para a construção das teorias do jornalismo. A indústria cultural, ao impor o que deve ser consumido, limita e condiciona a grande massa da população - processo comum também no meio jornalístico.

Outro autor ao qual tivemos de recorrer, Wilson da Costa Bueno, justifica-se pela tentativa de uma definição para a prática do jornalismo ambiental e científico, nos quais encontraremos parte significativa das reportagens levantadas.

Na visão de Melo (2000), o processo de seleção de notícias passa por critérios subjetivos ou particulares de interpretação da realidade, o que inibe a tomada de conhecimento da maioria dos leitores e favorece os interesses dos grupos dominantes.

Em síntese, o resgate de uma base teórica do jornalismo é fundamental para a análise da cobertura da imprensa sobre energia nuclear; isso porque encontraremos na prática jornalística muitas das advertências conceituais registradas pelos estudiosos da área, principalmente aquelas relacionadas ao processo mercadológico de fazer notícia, ou seja, que entende a notícia como um produto que segue as mesmas leis de mercado, portanto, os jornais publicarão assuntos que tenham apelo de venda.

No caso específico desta pesquisa, o medo histórico da população diante da energia nuclear é, hipoteticamente, um dos principais atrativos para vender notícias sobre o tema.

Ao longo da pesquisa, identificaremos a freqüência de pautas negativas e positivas sobre a questão nuclear.

A complexidade do tema é um fato; por isso, optamos por um estudo de caso que pudesse ilustrar a discussão teórica presente nesta pesquisa. Assim, pela presença constante na imprensa nacional e estrangeira, optamos, como estudo de caso, pela cobertura da imprensa sobre a energia nuclear após o lançamento do quarto relatório do IPCC, em fevereiro de 2007. 
O período da análise é de fevereiro de 2007, data de divulgação do relatório, até fevereiro de 2008, perfazendo um ano de estudo da cobertura jornalística.

A pesquisa foi centrada nos veículos impressos, uma vez que há diferenças significativas entre as mídias impressa, televisiva, radiofônica e on-line, que impedem o uso da mesma referência bibliográfica.

No período citado, foram encontradas 175 matérias publicadas nos jornais: A Cidade, Agora São Paulo, A Tribuna, Correio Brasiliense, Correio Popular, DCI, Diário de São Paulo, Diário do Grande ABC, Época, Exame, Folha de S.Paulo, Gazeta Mercantil, Isto É, Jornal do Brasil, Jornal da Tarde, Mogi News, O Diário, O Estado de S. Paulo, O Globo, Valor Econômico e Veja.

A análise da cobertura jornalística sobre a energia nuclear focou em três tipos de abordagens: negativa, positiva e mista, e no estudo das fontes de informação - uma vez que a fonte já é o seu próprio discurso, como ocorre com as ONGs ambientalistas, por exemplo.

\subsection{Objetivos}

Este trabalho tem por objetivos: (1) identificar o discurso predominante dos veículos de comunicação e das fontes de informação; (2) contribuir para o estabelecimento de políticas de comunicação com o público sobre os riscos da energia nuclear. 


\section{A ENERGIA NUCLEAR NO CENÁRIO DO AQUECIMENTO GLOBAL}

Até algum tempo atrás, o aquecimento global, o efeito estufa e outros temas eram tratados por restritos círculos científicos. É possível observar a disseminação desta temática através da mídia impressa, por exemplo:

"Se faltava alguma advertência digna de crédito sobre as conseqüências que o aquecimento global acarretará para as condições de vida do planeta, ela acaba de ser feita pelo relatório do Painel Intergovernamental sobre Mudanças Climáticas, divulgado em Bruxelas no último final de semana. Reunidos sob os auspícios da ONU, centenas de cientistas desenharam um cenário preocupante, a se formar no mundo inteiro em decorrência do aumento da temperatura provocado pelo efeitoestufa, este por sua vez oriundo do excesso de emissões de gás carbônico.” trecho de uma notícia publicada no jornal A Tribuna em 10/04/07.

As informações sobre o aquecimento são importantes, pois o tema é mundial e complexo. Os cenários previstos e as conseqüências de temperaturas mais elevadas serão sentidos por todos.

O efeito estufa é o processo natural que preserva o equilíbrio energético no planeta através da absorção de parte dos gases de efeito estufa (GEEs), como o dióxido de carbono $\left(\mathrm{CO}_{2}\right)$, o ozônio $\left(\mathrm{O}_{3}\right)$ e o metano $\left(\mathrm{CH}_{4}\right)$, que, juntamente com o vapor d'água, possuem a propriedade de absorver e refletir parte dos raios infravermelhos, contribuindo para aquecer a superfície terrestre.

A quantidade de gases de efeito estufa, principalmente o $\mathrm{CO}_{2}$, aumentou exponencialmente devido a inúmeros fatores, dentre eles à utilização de recursos naturais como o petróleo e a derrubada e queima de florestas. Esse aumento dos gases na atmosfera acarretou uma maior retenção da radiação infravermelha emitida pela Terra e, consequentemente, o aumento da temperatura do ar atmosférico. O aquecimento global, além do efeito na elevação da temperatura, poderá causar aumento na freqüência de eventos extremos, como secas, chuvas, ondas de calor e de frio, derretimento de geleiras e das calotas polares, entre outras conseqüências.

\subsection{O IPCC}

Em 1988, a conferência conjunta da Organização Meteorológica Mundial (OMM) e do Programa das Nações Unidas para o Meio Ambiente (PNUMA) impulsionou o 
movimento para a definição de ações com relação ao efeito estufa, com a criação do Painel Intergovernamental sobre Mudança do Clima (IPCC).

O IPCC é o órgão das Nações Unidas responsável por produzir informações científicas em relatórios que são divulgados periodicamente desde 1988, quando foi criado. Os relatórios são baseados na revisão de pesquisas de inúmeros cientistas de todo o mundo. A missão do IPCC é reunir o maior número possível de cientistas de diferentes países, com o objetivo de coletar e analisar a literatura "peer review" disponível sobre o aquecimento global e consolidar relatórios dos possíveis impactos e políticas de resposta às mudanças climáticas (AGRAWALLA, 1997).

As atribuições do IPCC compreendem:

1) avaliar as informações científicas e socioeconômicas disponíveis sobre as mudanças climáticas e seus impactos, assim como as opções para mitigar estas mudanças e a adaptação às mesmas,

ı) proporcionar, a partir de solicitação, o assessoramento científico, técnico e socioeconômico a órgãos internos da ONU sobre o tema.

Em 1990, em seu Primeiro Relatório de Avaliação, o IPCC (1991ª, p.xii) anunciava que os cinco anos mais quentes jamais registrados haviam ocorrido na década de 1980. Dali em diante, essa afirmação ganharia atualizações frequentes, revelando recordes cada vez mais preocupantes. No início dos anos 1990, Clive Ponting (1995, p. 618) dizia que a década de 1980 havia trazido seis dos dez anos mais quentes, e que 1990 era o ano mais quente registrado.

Com base nos resultados do Primeiro Relatório de Avaliação do IPCC (HOGHTON et al, 1990), negociou-se o texto final da Convenção - Quadro das Nações Unidas sobre Mudanças do Clima (CQNUMC), com a adoção de metas voluntárias de redução de emissão de gases de efeito estufa.

O Segundo Relatório de Avaliação do IPCC (1995) afirmava que os últimos anos estavam entre os mais quentes (IPCC, 1995, p.22). As metas de redução voluntária tiveram resultados insatisfatórios, sendo que apenas alguns poucos países conseguiram de fato reduzir emissões, resultado muito mais de mudanças de políticas energéticas do que de um trabalho objetivo em busca da redução de emissões. Em 1997, foi acordado o Protocolo de 
Quioto à Convenção Clima, impondo reduções de emissões de cerca de 5\%. Em 2001, o Terceiro Relatório de Avaliação afirmava que 1998 e os anos 1990 haviam sido o ano e a década mais quentes registrados (IPCC, 2001 a, p.2). Em 2007, o IPCC lança o seu Quarto Relatório de Avaliação, com os dados mais recentes disponíveis: entre 1995 e 2006 estariam onze dos doze anos mais quentes já registrados (IPCC, 2007ª,p.5).

O Quarto Relatório de Avaliação do IPCC registra que entre 1850 e 2005 a temperatura média global teria aumentado $0,76^{\circ} \mathrm{C}$. Esse aumento pode ser decomposto em dois períodos: de 1850 a 1906, e de 1906 a 2005 . A maior parte do aumento - $0,74^{\circ} \mathrm{C}$ - teria ocorrido no segundo período, deixando uma elevação bem menor para o período anterior. Isso pode indicar que o aumento de temperatura foi maior em décadas mais recentes. $\mathrm{O}$ Terceiro Relatório de Avaliação já apontava que o aumento de temperatura entre 1901 e 2000 havia sido de $0,6^{\circ} \mathrm{C}$, o que reforça a idéia de aumentos maiores nos últimos anos. Nos últimos 50 anos, a temperatura média global vem aumentando $0,13^{\circ} \mathrm{C}$ por década, isto é, quase o dobro da tendência dos últimos 100 anos.

Além dos trabalhos do IPCC, que sugerem cenários de mudança projetados para os possíveis cenários, o marco dessa preocupação é o recente relatório divulgado pelo economista inglês, Nicholas Stern. A pedido do G8 (Grupo dos oito países mais desenvolvidos), o trabalho quantifica em dados econômicos os estragos causados pelo aquecimento na sociedade e ainda quais as possibilidades de minimizar os impactos.

Stern (2006) indica que, baseado nos modelos econômicos atuais, se não houver ações para combater o problema, serão necessários aproximadamente $5 \%$ da economia mundial por ano destinado aos efeitos do aquecimento. Entretanto, se os mais extremos riscos de problemas ambientais ocorrerem, serão necessários $20 \%$ da economia global por ano destinados aos efeitos do aquecimento. No entanto, Stern (2006) diz que, se existirem ações fortes, esse número cairá para $1 \%$ da economia mundial por ano.

O mundo foi alertado da urgência de se estabilizar a emissão dos gases que causam o efeito estufa. Hansen et al (2006) afirma que a inferência de uma mudança climática perigosa pode estimular a discussão de "consertos de engenharia" para reduzir o aquecimento global. Afirmam os autores que a noção de "conserto" sozinha é perigosa, pois poderia diminuir os esforços individuais para reduzir a emissão de $\mathrm{CO}_{2}$, e pode ser irresponsável não considerar todos os meios possíveis. Completam afirmando que esses meios devem ser utilizados de maneira abrangente, e também que se tem claro hoje a 
inexistência de uma grande e única solução para o problema, bem como a certeza da responsabilidade coletiva e, nesse sentido, os esforços devem ser amplos.

O Brasil tem-se destacado por apresentar reduzidos índices de emissão comparativamente ao resto do mundo. Basicamente, isso se deve ao elevado percentual de participação de fontes renováveis de energia na matriz energética brasileira, que, em 2005, foram responsáveis por $44,5 \%$ da oferta interna de energia no país.

\subsection{A Matriz Energética Brasileira}

O Brasil tem uma capacidade instalada de 104.816 MW (megawatts), com 1768 usinas instaladas, sendo 159 hidrelétricas, 1.042 térmicas abastecidas por fontes diversas (gás natural, biomassa, óleo diesel e óleo combustível), 320 Pequenas Centrais Hidrelétricas (PCHs), 2 nucleares, 227 centrais geradoras hidrelétricas e uma solar. (ANEEL, 2008).

Em 2007, de acordo com a RESENHA ENERGÉTICA BRASILEIRA, observa-se uma tendência crescente da participação de fontes de origem fóssil, notadamente o gás natural, cuja participação passou, de 3,7\% em 1998, para 9,3\% em 2007. Porém, observase uma tendência decrescente de participação de fontes fósseis relativamente mais emissoras de dióxido de carbono, como as originárias de óleos combustíveis. O Plano Decenal de Expansão 1999/2008, elaborado pela Eletrobrás, prevê um aumento da participação de energias renováveis. No entanto, as fontes compreendidas no conceito mais restrito de "renováveis" (solar, eólica, biomassa, etc.) poderão permanecer inexpressivas no todo.

O Gráfico 1 apresenta a participação percentual das fontes para a geração de energia elétrica no Brasil. 




Gráfico 1 - Participação percentual das fontes para a geração de energia elétrica no Brasil. Fonte: Resenha Energética Brasileira 2007, MME

No Brasil, a hidroeletricidade é a principal fonte energética, correspondendo a $77 \%$ da oferta total de energia. É uma energia "limpa", entretanto, essa alternativa, na sua concepção, apresenta problemas de perdas de enormes extensões de solo agriculturável que ficam alagados; perdas de jazidas nas regiões alagadas, por exemplo a argila para a fabricação de telhas e tijolos; modificação do regime do rio, passando de um regime terrestre-fluvial para um regime lacustre, com perdas de espécies que não conseguem se adaptar ao novo habitat; modificação do ecossistema e do clima local, que ficam mais úmidos; problemas por ocasião do enchimento da barragem (árvores apodrecendo formando gases, eutrofização, problemas com a qualidade da água estagnada; proliferação de mosquitos e plantas aquáticas nas barragens; assoreamento do lago por retenção de sedimentos.

O petróleo e o gás natural na fase de exploração acarretam riscos para os trabalhadores envolvidos, incêndio, e vazamentos para o mar, já que a maior parte do nosso petróleo é extraída da plataforma continental.

A mineração de carvão causa problemas ocupacionais e ambientais conhecidos: exposição de trabalhadores da mina a particulados, riscos de acidentes, erosão e perda de terrenos nunca mais recuperados devido ao alto custo e baixo valor da terra, acidificação do solo e das águas por causa da drenagem, emissão de particulados. Em seu beneficiamento para a redução das cinzas de enxofre, são geradas grandes quantidades de refugos, que ficam estocadas a céu aberto e que não tem um destino adequado. Essas 
pilhas, juntamente com o carvão, ficam expostas à chuva que, atacando a pirita, causa drenagens ácidas, contaminando os aqüíferos e cursos d'água.

A lenha ainda é utilizada na zona rural para cozimento de alimentos, e em pequenas indústrias próximas às regiões produtoras como: olarias, cerâmicas, pequenas indústrias alimentícias, pizzarias etc.; o efeito sobre a poluição do ar não é muito relevante, porém, é importante registrar as conseqüências sobre a destruição das matas nativas, como vem acontecendo com elevada intensidade no semi-árido nordestino.

\subsection{A Energia Nuclear}

No final de 2006, a energia nuclear ocupou o quarto lugar entre as principais formas para a produção de energia elétrica no mundo, antecedidos pelo carvão, gás natural e hídricas segundo a Tab. 1. Geração de Energia elétrica no mundo.

Tabela 1 - Geração de Energia elétrica no mundo (2006)

\begin{tabular}{|c|c|c|}
\hline Pais & $\%$ & TWh* \\
\hline Carváo & 41,0 & $7.761,3$ \\
\hline Petroleo & 58 & $1.097,94$ \\
\hline Gass Natural & 20,1 & $3.804,93$ \\
\hline Nuclear & 14,8 & $2.501,64$ \\
\hline Hidreletrica & 16,0 & $3.028,8$ \\
\hline Outras & 2,3 & 435,39 \\
\hline Total & 100,0 & 18.930 \\
\hline
\end{tabular}

(*) Um terawatt-hora equivale a um milhão de gigawatts-hora. Fonte: AIEA, 2008 
A energia nuclear vive um novo ciclo de expansão. Além de novas unidades em construção, aumenta o número de países que buscam aderir a essa tecnologia ou expandir o que já tem instalado.

Segundo dados da Agência Internacional de Energia Atômica (AIEA), existiam 439 reatores nucleares, em 2006, distribuídos em 31 países; os Estados Unidos concentram o maior número de unidades, 104, acompanhados pela França, com 59 reatores, seguida pelo Japão, 55, conforme mostra a Tabela 2.

Tabela 2 -Número de centrais nucleares e potência instalada em 2007 no mundo

\begin{tabular}{|c|c|c|c|}
\hline & Pals & Unidisde: & MW \\
\hline 1 & Estados Unidos & 104 & 100.582 \\
\hline 2 & franca & 59 & 62.260 \\
\hline 24 & Jasso & 55 & 47587 \\
\hline+ & Rossia & 31 & 21.743 \\
\hline s & Nemanha & 17 & 20470 \\
\hline$\theta$ & Cores & 20 & 17.451 \\
\hline 74 & Uatana & 15 & 13.107 \\
\hline ge & Cansds & 18 & 12621 \\
\hline get & Asino Urido & 19 & 10.222 \\
\hline $10+$ & Suects & 10 & 9.014 \\
\hline \multirow[t]{2}{*}{230} & Brasil & 2 & 2.007 \\
\hline & Total & 439 & 372.100 \\
\hline
\end{tabular}

Fonte: AIEA (Adaptado), 2008

Um total de 37 reatores encontra-se em construção em 14 países (Tab3), enquanto as obras de seis usinas tinham início na Coréia do Sul, Rússia, França e China. Além disso, três usinas entraram em operação na Índia, China e Romênia. Os Estados Unidos reativaram outras duas unidades, paralisadas há vários anos. 
Tabela 3 - Energia nuclear: unidades e potência em construção em 2007

\begin{tabular}{|c|c|c|}
\hline Pals & Unidades & MW \\
\hline Atgertina & 1 & $\infty 2$ \\
\hline Bulgaria & 2 & 1.900 \\
\hline China & 6 & 5.220 \\
\hline Firisindia & 1 & 1.000 \\
\hline Franca & 1 & 1600 \\
\hline Indis & 6 & 2910 \\
\hline Ira & 1 & 915 \\
\hline tapso & 2 & 2.191 \\
\hline Corela & 4 & 3.840 \\
\hline Paquiarso & 1 & 300 \\
\hline Pasia & 7 & 4724 \\
\hline Dahwan & 2 & 2000 \\
\hline Uasnia & 2 & 1.900 \\
\hline Estados Unidos & 1 & 1.165 \\
\hline Total & 37 & 31.563 \\
\hline
\end{tabular}

Fonte: AIEA, 2008

O ressurgimento da energia nuclear no contexto energético mundial tem sido ocasionado pela necessidade de diversificação da matriz energética, sendo apontada como uma alternativa viável ambientalmente, de forma a atender o consumo crescente de energia, sem contribuir para o aquecimento global. O dióxido de carbono ou qualquer outro gás que contribua para o efeito estufa é muito baixo na cadeia produtiva da energia nuclear.

\subsubsection{A Situação da Energia Nuclear no Brasil}

A partir dos anos 50, o Governo Brasileiro estimulou o desenvolvimento da tecnologia nuclear, até então as atividades no setor destacavam-se pelos cunhos teórico e acadêmico. Nesta época, ocorreu a criação do Conselho Nacional de Pesquisas (CNPq), onde sucederam as primeiras tentativas para a formulação de uma Política Nacional de Energia Nuclear e a criação da Comissão Nacional de Energia Nuclear (CNEN).

A produção de energia nuclear tinha o objetivo primordial de propiciar ao setor elétrico a oportunidade de travar conhecimento com esta moderna tecnologia e adquirir experiência para fazer face às possíveis necessidades futuras. 
Em 1972, através de um acordo com os EUA, o Brasil adquiriu um reator de potência a urânio enriquecido, que deu origem a primeira unidade da central, chamada Angra I. Já Angra II e Angra III foram desenvolvidas em meados de 1975, após ser firmado um Acordo de Cooperação para Uso Pacífico da Energia Nuclear entre Brasil e Alemanha.

Ao final da década de 70, segundo o Plano Nuclear Brasileiro, ao perceber que o desenvolvimento da tecnologia nuclear em associação com outros países poderia não atender às necessidades nacionais, o Governo Brasileiro passou a conduzir um Programa Autônomo - Programa de Desenvolvimento de Tecnologia Nuclear (PDTN).

Angra I, com potência de 657MW, entrou em operação em 1985. Angra II, com potência instalada de 1350MW, em 2000. Em 2007, Angra I e Angra II responderam por $2,5 \%$ da produção total de energia elétrica do país.

Angra III, também com 1350MW teve sua obra paralisada por muitos anos. A construção foi inserida no Plano Decenal de Expansão de Energia Elétrica 2006/2015 e, em julho de 2008, o Instituto Brasileiro do Meio Ambiente e Recursos Naturais (Ibama) expediu a licença prévia autorizando a retomada das obras. A operação de Angra III está prevista para início de 2013. O Plano Nacional de Energia PNE 2030 prevê, além de Angra III, a implantação de mais quatro usinas nucleares até 2030.

Tabela 4 - Usinas existentes suas potências e futuras instalações

\begin{tabular}{|c|r|c|}
\hline USINA & POTÊNCIA & STATUS \\
\hline Angra 1 & $650 \mathrm{MW}$ & Em operação \\
\hline Angra 2 & $1.350 \mathrm{MW}$ & Em operação \\
\hline Angra 3 & $1.350 \mathrm{MW}$ & 2013 \\
\hline Nuclear 4 & $1.000 \mathrm{MW}$ & Previsão - até 2020 \\
\hline Nuclear 5 & $1.000 \mathrm{MW}$ & Previsão - até 2025 \\
\hline Nuclear 6 $\times 7$ & $2 \times 1.000 \mathrm{MW}$ & Previsão - até 2030 \\
\hline Total & $7.350 \mathrm{MW}$ & \\
\hline
\end{tabular}

Fonte: INB, 2007 
O Programa Nuclear Brasileiro (PNB), com os investimentos do passado, desenvolveu tecnologias próprias e hoje o Brasil está incluído no rol dos 10 países que dominam a tecnologia nuclear, não só para a produção de energia elétrica, mas em todos os campos de aplicação.

No final da década de 90, a renascença da energia nuclear fez com que o governo desse uma atenção estratégica ao PNB, devido à demanda de geração de energia de forma limpa. Sua organização é apresentada no organograma a seguir.

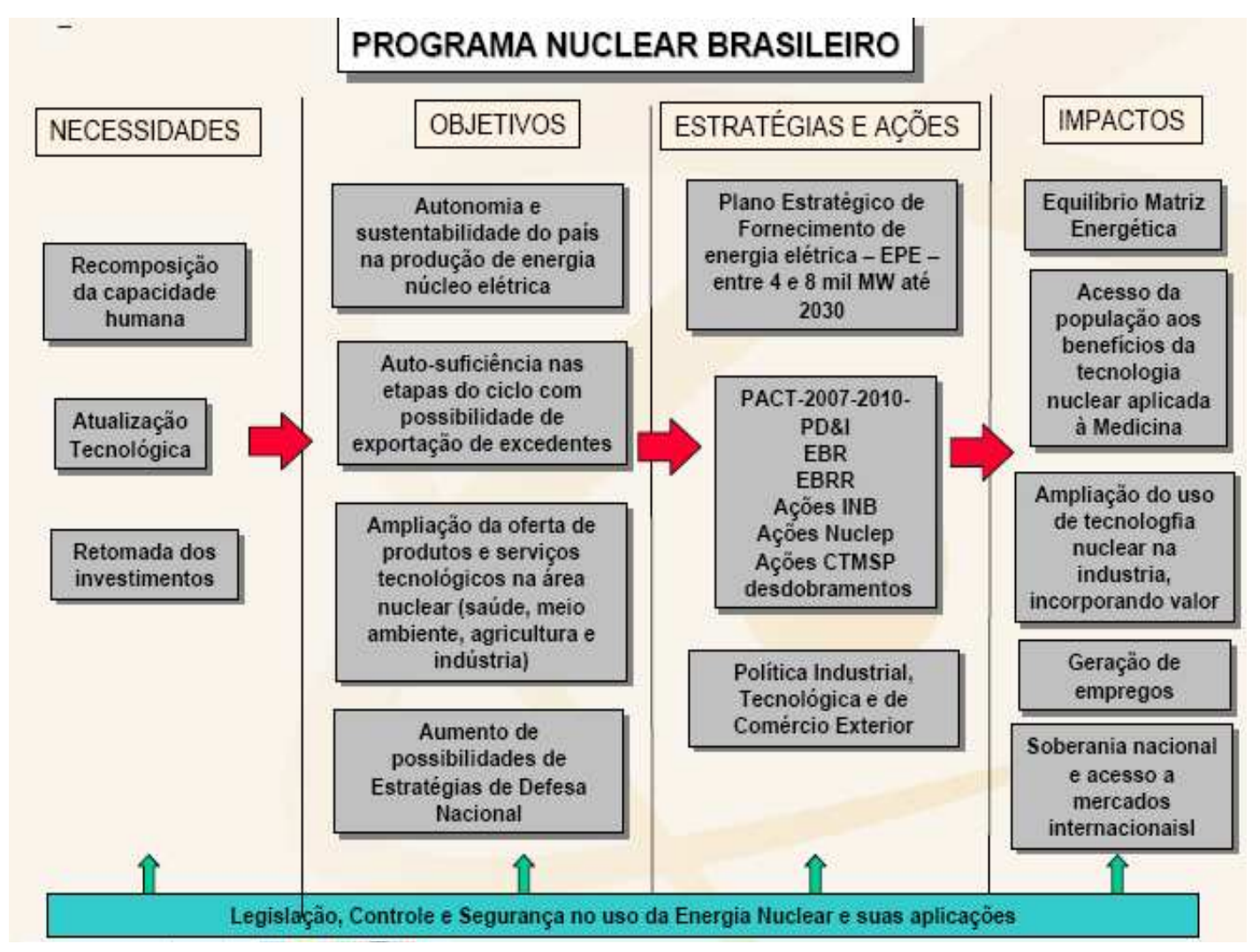

Figura 1 - Estrutura do Programa Nuclear Brasileiro Fonte: CNEN, 2007

O PNB não se restringe à geração de eletricidade. Hoje, a tecnologia nuclear engloba muitas outras áreas de aplicação: na medicina, a produção de radiofármacos, esterilização de equipamentos, radiodiagnósticos e radioterapia; na indústria esterilização de alimentos; radiografia industrial; levantamentos geológicos, levantamentos de aqüíferos; entre outras. 
O Brasil detém uma das maiores reservas globais de urânio. Segundo dados INB, o país registra a sexta maior reserva, calculada em 309.000t de U2O8.

\section{Reservas de Urânio Conhecidas}

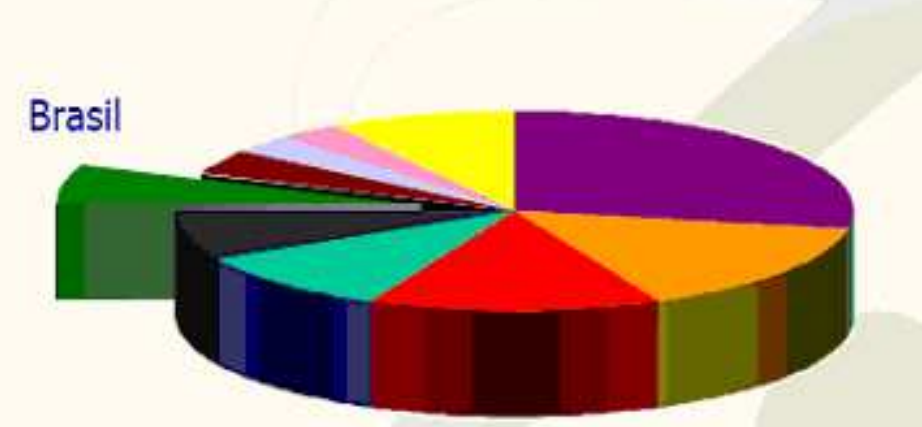

Brasil : A reserva conhecida de Urânio no Brasil é de $\underline{309.000}$ toneladas, sendo a $6^{\mathrm{a}}$ reserva mundial. Essa reserva corresponde a apenas $30 \%$ do território prospectado, apenas até $100 \mathrm{~m}$ de profundidade e seria suficiente para operar Angra I, II e III por mais 520 anos. 


\section{O PAPEL DA IMPRENSA NA FORMAÇÃO DA PERCEPÇÃO DE RISCOS}

\subsection{A Percepção de Riscos Nucleares}

O termo percepção designa o ato pelo qual tomamos conhecimento de um objeto do meio exterior. A percepção é tratada como apreensão de uma situação objetiva baseada em sensações, acompanhada de representações e, freqüentemente, juízos. Na percepção, acrescentamos elementos da memória, do raciocínio, do juízo e do afeto, portanto, acoplamos as qualidades objetivas dos sentidos a outros elementos.

Os estudos de percepção de risco surgiram de uma demanda das avaliações e da comunicação de riscos devido os conflitos quanto à percepção dos mesmos entre especialistas e leigos.

A percepção de riscos pode ser definida como sendo a "habilidade de interpretar uma situação de potencial dano à saúde ou à vida da pessoa, ou de terceiros, baseada em experiências anteriores e sua extrapolação para um momento futuro, habilidade esta que varia de uma vaga opinião a uma firme convicção” WIEDERMANN, 1993.

Cada indivíduo constrói a sua percepção de risco baseada sem suas crenças e vivências. Mas é possível considerar que grupos populacionais específicos tendem a apresentar padrões semelhantes de percepção de riscos, fruto da convivência e da experimentação comum.

Pode-se dizer que os estudos de percepção ambiental estão relacionados com os esforços para entender como os homens se estruturam em suas próprias mentes e o mundo que os cerca. Vale ressaltar que percepção de risco introduziu a subjetividade ao conceito de risco.

Na década de 60, o estudo da percepção de risco surgiu devido a oposição do público em geral a alguns riscos tecnológicos, especialmente a tecnologia nuclear. A forma distinta de como o público em geral e os especialistas enxergavam o risco precisava ser entendida e administrada. Os primeiros estudos norteavam-se por meio das comparações de riscos. Swoby (1965), por exemplo, questionava-se como "uma pessoa assumia o risco de dirigir fumando, mas não aceitava a instalação de uma usina nuclear?"; alguns anos 
depois, Starr (1969) esclarecia que a sociedade aceitava melhor alguns riscos, pois os mesmos estavam associados a benefícios ou eram riscos voluntários.

O objetivo da percepção de riscos é tentar responder a inúmeras questões, examinando as opiniões expressas pelas pessoas quando questionadas a avaliar riscos a que estão, ou que poderão estar sujeitas no futuro. Percebeu-se que, compreendendo as formas como as pessoas pensam e respondem ao risco, poder-se-ia melhorar a comunicação entre os tomadores de decisão e o público em geral.

As abordagens psicológicas do risco tentavam identificar quais fatores são levados em consideração na formação da opinião das pessoas sobre risco.

Nas décadas de 70 e 80 foram desenvolvidos os principais estudos de percepção de risco pelos psicólogos Fischhoff, Slovic e Lichenstein (1978), conhecidos como estudos psicométricos, que tratam o risco como um fenômeno subjetivo e dependente de uma correlação de fatores psicológicos, sociais, institucionais e culturais.

Esta metodologia permitiu que as pessoas pudessem dar respostas a questões complexas, demonstrando que era possível medir e quantificar a percepção de riscos. A partir dos resultados dos estudos, passou-se a poder identificar as semelhanças e as diferenças entre grupos nas suas percepções de riscos. Isto se chama risco percebido, e demonstra que o conceito de risco pode ter diferentes significados para diferentes pessoas, como por exemplo, para os especialistas e o público em geral. O resultado desses estudos determinou o conceito de risco percebido.

A tecnologia nuclear não está limitada somente à geração de eletricidade, mas sim em um grande número de aplicações: na saúde, emprego de radioisótopos ou radiações em medicina nuclear, para fins de diagnóstico, esterilização de equipamentos e materiais hospitalares; na agricultura, preservação de alimentos, estudos de solos e plantas, utilizando traçadores radioativos; na indústria, análise não-destrutiva de materiais, medidas de processos industriais empregando radioisótopos como traçadores, modificação de materiais pela radiação. Em todos esses campos, são desenvolvidas pesquisas científicas voltadas à melhor qualidade de vida da população.

O público em geral, além de desconhecer a diversidade de aplicações da energia nuclear em nosso dia-a-dia, percebe a mesma de forma negativa. 
Segundo Smith, citado por Slovic, Flynn e Layman (1991), “a energia nuclear foi concebida em segredo, nasceu na guerra, e pela primeira vez revelada ao mundo numa cena de horror".

A possível utilização da tecnologia para fins bélicos, como salienta GIROTTI, 1984, também associou a percepção negativa que a população apresenta sobre a energia nuclear com os usos militares: "Desde o início, as pesquisas (sobre energia nuclear) foram rapidamente canalizadas em direção aos objetivos bélicos, só depois de Hiroshima, esta tendência se combinou com o aproveitamento comercial - pacífico (usinas termonucleares, medicina, etc.). Mas, em nenhum momento, foi abandonada a orientação mestra."

Além das duas variáveis descritas acima, há os acidentes nas usinas de Three Mile Island, nos EUA, em 1979, e de Chernobyl, na Rússia em 1986, que atingiu dimensões assustadoras e a questão dos rejeitos radioativos preocupam a todos.

Os EUA, a Inglaterra e a França, entre outros países, enfrentaram sérios problemas sociais por causa da questão nuclear nos anos 70 e 80, desenvolveram várias metodologias de pesquisas baseadas em estudos de percepção de risco.

A segurança das plantas nucleares seguia uma abordagem determinística, no final da década de 70, após o acidente da usina Three Mile Island. Em 1982, USNRC publicou o primeiro guia ou diretriz para orientar a execução de uma análise de percepção de risco. Em meados da década de 90, a PRA foi efetivamente considerada e incorporada no processo de aprovação e licenciamento de plantas nucleares nos EUA.

A energia nuclear polariza defensores e opositores em relação à ausência ou presença de um risco tecnológico a instalação de reatores nucleares, fenômeno verificado não apenas no Brasil, mas no mundo inteiro.

Uma série de estudos promovida pelo Centro de Pesquisas de Risco em Estocolmo, promovida por Drottz e Sjöberg, buscou entender a percepção de risco do público em geral e dos especialistas associada com a tecnologia nuclear.

Algumas constatações são feitas por este estudo e outros que tratam do tema:

a) $\mathrm{O}$ público desconhece os fatos sobre a energia nuclear e tem noções equivocadas sobre uma série de conceitos essenciais para que ela seja compreendida, particularmente sobre os rejeitos radioativos. 
b) O público rejeita a energia nuclear porque considera que os riscos são muito altos, além de acreditar que ainda não foram encontradas soluções seguras para a deposição definitiva dos rejeitos radioativos.

c) O público rejeita a energia nuclear porque considera os custos muito elevados quando comparada a outras fontes de energia.

d) O público prefere as chamadas "energia renováveis", por acreditar que sejam ecologicamente melhores.

e) O público desconfia das autoridades do setor nuclear, por considerar que tenham interesses de natureza militar e geopolítica não declarados.

Muitas causas podem ser atribuídas para as distorções que ocorrem na percepção de riscos relacionadas à energia nuclear, dentre elas se destacam:

a) as falhas no processo de comunicação entre o setor nuclear (empresas fornecedoras de energia, instituições de pesquisa, autoridades regulamentadoras e fiscalizadoras, etc) e o público em geral;

b) o setor nuclear, via de regra, ignora os princípios fundamentais da teoria de comunicação, transmitindo freqüentemente mensagens de natureza defensiva, num discurso longo e complexo, que poucas pessoas podem entender e estão dispostas a escutar.

Explicitar a forma como a mídia impressa retrata temas relacionados aos problemas ambientais não é uma tarefa fácil, principalmente ao tratar a energia nuclear. É preciso ter os objetivos muito claros, para que não se corra o risco de discutir o assunto de maneira tangencial em função de sua amplitude.

Dessa forma, optou-se, neste capítulo, por realizar a introdução ao campo jornalístico como tentativa de descobrir qual o efeito das mensagens noticiosas ao público, ou seja, se tais informações contribuem para uma percepção mais adequada das questões ambientais. 


\subsection{O Papel Social da Prática Jornalística}

Segundo o Instituto Ethos (2002 apud Pereira, 2002), a importância das informações pode ser avaliada sob diversas perspectivas, mas em qualquer sistema a perspectiva essencial é a do usuário da informação. O principal papel da informação é gerar subsídios para a tomada de decisões, e as personagens principais deste processo são as pessoas.

De acordo com De Fleur e Ball-Rokeach (1968), a influência das mensagens noticiosas na sociedade de massa tem sido discutida ao longo do último século por pesquisadores que produziram diversas hipóteses sobre esse fenômeno, contribuindo, assim, para a construção do conhecimento teórico contemporâneo sobre a mídia voltado à massa.

Ao analisar a divulgação científica, parece claro que informar, educar e, conseqüentemente, formar opinião dos indivíduos sobre os assuntos que afetam o cotidiano têm sido meios pelos quais os veículos de comunicação contribuem de forma marcante na construção e reprodução da realidade sócia, aponta De Fleur e Ball Rokeach (1968).

Esse fenômeno de formação das opiniões da população é chamado de opinião pública. No entender de James Bryce (apud Melo, 2000), só existe a Opinião Pública quando os indivíduos de uma sociedade têm acesso livre às informações da atualidade e, em conseqüência, podem formular opiniões autoconscientes.

Marx (apud Melo, 2000:95) aponta que "na mesma medida que é um produto da Opinião Pública, a imprensa livre cria também essa opinião". Ou seja, de acordo com os dois teóricos acima referidos, quando existe o acesso igualitário às informações pelos cidadãos, estes são capazes de formular opiniões e agir democraticamente, demonstrando a possibilidade das matérias jornalísticas criarem maneiras e ferramentas para que as pessoas possam exercer a cidadania.

Porém, nem sempre foi assim, já que os estudos da comunicação, em dado momento, descartaram essa possível função da comunicação de educar e formar cidadãos. $\mathrm{Na}$ verdade, a corrente que realizou esse estudo indicava que a comunicação poderia estar nas mãos de pessoas que tivessem más intenções. A imprensa, segundo esses teóricos, era utilizada como instrumento de poder e alienação. 
Uma das escolas que iniciaram o estudo dos efeitos da comunicação foi a de Frankfurt; nela, os estudiosos buscavam a interpretação dos resultados e dos efeitos das mensagens. De acordo com a visão dessa corrente, José Marques de Melo assim define os meios de comunicação:

Os meios de comunicação social constituem, paradoxalmente, meios de elite e de massas. Como instrumentos mecânicos e eletrônicos que difundem mensagens de acesso potencial a todos os indivíduos da sociedade, eles são meios que atingem as massas, atuando como intermediários entre elas e o mundo... No entanto, é preciso considerar que, embora atingindo a massa (público heterogêneo, anônimo, disperso), os meios de comunicação social são de elite, ou seja, são meios controlados pela elite

(Melo, 1971:12).

Em síntese, o resultado por essa visão é que quem obtém o controle dos meios produtivos da comunicação está submetido às linhas editoriais e interesses, como o da organização que trabalha. Na prática, as mensagens e o caráter público (pré-definidos pelos emissores) atendem a seus interesses, segundo Medina:

Logo se percebe também que os próprios avanços tecnológicos fazem parte das necessidades da industrialização, ou que reforçam a informação, no caso, jornalística, como decorrência normal do sistema econômico que está na base. Nesse momento, é preciso examinar o problema no seu enquadramento geral: informação jornalística como produto da comunicação de massa, comunicação de massa como indústria cultural e indústria cultural como fenômeno da sociedade urbana e industrializada"

(Medina, 1998:16.)

Essa é a linha predominante da corrente frankfurtiana, desenvolvida na década de 40, fundamentada na pesquisa teórico-ideológica, como forma de uma crítica àqueles que defendem que os meios de comunicação fortalecem a democracia e a cidadania. Essa escola, com bases marxistas, é principalmente focada na comunicação como forma de dominação, alienação e poder.

Horkheimer e Adorno chamaram a atenção para o caráter industrial da comunicação e da conseqüente transformação do produto cultural em mercadoria, processo que visa basicamente à obtenção de lucro, aponta Ramos (1994). Ao difundir regras e comportamentos, a comunicação tolhe a reflexão e barra o senso crítico, dificultando o receptor de ter uma autonomia em analisar e perceber o mundo em que está inserido. 
Diversos estudiosos dessa linha ainda afirmam que a notícia é um produto semelhante à publicidade, a qual está dentro das regras de mercado e do poder, ou seja, além de aliar a publicidade com o jornalismo, esses teóricos consideram a notícia como um produto qualquer.

Marcondes Filho (1989), por exemplo, diz que existe um "carregamento de (...) apelos estéticos e sensoriais (...) que buscam ser agradáveis ao público e que ainda atendem às normas de “(...) generalização, padronização, simplificação e negação do subjetivismo em que se baseia a prática do jornalismo". Essa classificação e características das notícias, segundo o autor, são semelhantes à publicidade e à venda de qualquer produto.

Esses códigos e técnicas pertencentes à prática do jornalismo, além de aproximar a mensagem a um produto, tornam as mensagens como verdade absoluta e inquestionável à massa, cuja compreensão e crítica já se encontram tolhidas de acordo com as premissas da indústria cultural.

Contrário à corrente alemã, Genro Filho (1987) acredita que, no jornalismo, existem características específicas e potencialidades, e expressa a relação da profissão com a Indústria Cultural:

A idéia de cultura como manipulação e do jornalismo como fenômeno redutível a sua forma mercantil, dotado de conteúdo essencialmente alienado e alienador, é uma das conseqüências teóricas dessa suposta unidade em processo de fragmentação radical e irresistível (Genro Filho 1987:93).

Assim, os desdobramentos da Teoria Crítica mostram-se extremamente negativos e pessimistas ao generalizar os personagens da comunicação, quando os consideram uma massa na sociedade urbana e industrial. Conforme Cardoso (apud Melo, 1999), o resultado sem opções na questão cultural na sua dimensão plural, além de criticar a linguagem elitista e a pretensão de salvar da massa aqueles que oferecem resistência ao sistema e, ilusoriamente, não são influenciados pela indústria de massa.

Ramos (1994) diz que essa visão de que os meios de comunicação são onipotentes não é totalmente eficaz, uma vez que, historicamente, o controle exercido pelos detentores do poder não evitou as transformações sociais e de regimes de governo, portanto sendo possível que esta não seja tão eficaz, como dizem os teóricos alemães. 
De acordo com esses estudiosos, fica claro que não é possível descartar a força de persuasão dos meios de comunicação para estabilizarem a ordem social; entretanto, parece errado afirmar enfaticamente que a comunicação é aceita pela massa sem nenhuma resistência.

Ramos (1994) cita alguns outros teóricos que estudaram os efeitos da comunicação nas pessoas e que demonstraram que existem formas de resistência da massa:

Pesquisas realizadas por diversos estudiosos da comunicação como Lazarsfield, Klapper, Merton, Hovland, Maccoby, Ball-Rockeach e deFleur, Lins da Silva, entre outros (7), revelaram que, pela natureza complexa da comunicação, os efeitos que ela gera dependem de uma interação entre os meios, as mensagens, as intenções do comunicador, as preferências e predisposições do receptor, as condições gerais que interpenetram todo o processo comunicacional.

(Ramos 1994: 6).

Alberto Dines (apud Melo 2000) analisa essa questão de maneira prática, ao mostrar a discrepância entre o que quer os donos dos jornais e o que querem os leitores. Poderá ser fatal, se considerarmos que, no aperfeiçoamento da sociedade, os jornais cada vez mais assumem o papel de serviço público, verdadeiros portadores de câmaras-de-eco do grupo social que representam.

Melo (2000) aponta que, no regime capitalista, os meios de comunicação de massa são empresas industriais, submetidas às leis de oferta e procura. Vendem seus produtos mensagens de informação, educação ou lazer como as demais, atuando em favor do público.

O que se percebe nos autores citados e, principalmente em Genro Filho (1987), é uma função mais ampla do jornalismo, que deve ser pensada em suas especificidades. Embora tradicionalmente seja derivado da burguesia e reproduza tal visão, existem características importantes enquanto forma de conhecimento social e extrapola essa funcionalidade do sistema capitalista.

É visível o pessimismo alemão no cotidiano jornalístico através das práticas profissionais que se submetem à indústria da notícia, reconhecendo-se, portanto, além do efeito teórico, as atribuições práticas desta escola. No entanto, é na crítica às suas teorias, fundamentada nas finalidades potenciais do jornalismo, que se fortalece a base para este estudo. 
(...) as possibilidades de manipulação, proporcionadas pelos meios de comunicação de massa, são tão significativas quanto às potencialidades de desalienação e de autoconstrução consciente, se tais meios forem pensados numa perspectiva revolucionária e efetivamente socialista. (Genro Filho, 1987: 89)

Desta forma, Genro Filho (1987) vê com certa dificuldade a criação de um novo tipo de jornalismo que seja capaz de revolucionar o jornalismo baseado em técnicas industriais. $\mathrm{O}$ autor ainda tem uma preocupação da prática responsável na criação do conhecimento, com base na responsabilidade diante dos fatos e sua legitimidade, na idoneidade, articulando idéias e moldando a cidadania. Esses critérios de singularidade, particularidade, universalidade e a relação desses termos são o significado do jornalismo, que deve ser ingrediente para a formação do conhecimento social e a apreensão da realidade, contrapondo os ideais de Frankfurt, atuando como instrumento com a potencialidade de desalienar e dar condições para que as pessoas pensem e posicionem-se diante dos acontecimentos coletivos.

\subsection{O Discurso Jornalístico}

Para prosseguir a pesquisa, faz-se necessária a delimitação do campo do jornalismo ambiental, cuja prática ainda é recente. Inicialmente, as coberturas jornalísticas sobre o meio ambiente eram realizadas apenas de maneira pontual, principalmente ligada a desastres e catástrofes ambientais. De acordo com Candia (2002):

Mas apesar da "boa intenção" da mídia em publicar fatos relacionados ao meio ambiente, muitas vezes isso tem sido feito de forma errada, desviando o foco para o que deveria ser realmente tratado. Matérias relacionadas ao meio ambiente tornaram-se uma espécie de jornalismo-tragédia, ou seja, basta acontecer alguma desgraça ambiental para que vire notícia. Quando não, publica-se o "jornalismoemotivo", que sempre anuncia alguma espécie ameaçada de extinção - geralmente com a foto do possível animal extinto com uma cara de piedade que, só de olhar, corta o coração do mais desalmado dos seres humanos (Candia, 2002:2).

Na visão de Belmonte (1997:1), a imprensa brasileira não aprofunda o debate, exceto alguns jornalistas que atuam isoladamente. "O meio ambiente é manchete e ganha espaço e tempo na cobertura diária quando acontecem desastres, ou quando os assuntos repercutem no exterior". 
Essa opinião de alguns autores acaba criando uma discussão sobre o que é realmente o jornalismo ambiental, e em qual editoria ele deve estar. Claramente a pauta ambiental busca, na área da ciência, as respostas e as fontes dos temas tratados para compreender os fatos interligados.

Belmonte é um dos que fazem uma diferenciação e defende o afastamento entre as editorias de ciência e de meio ambiente, baseado na responsabilidade do repórter diante dos fatos. O autor ressalta que:

O compromisso com a vida e o conflito civilização x natureza marcam o discurso do jornalismo ambiental. Já uma reportagem científica não tem necessariamente este olhar quando se apresenta como jornalismo científico. Acredito que uma matéria sobre o funcionamento de uma bomba atômica se enquadre no campo jornalismo científico. Já Hiroshima, de John Hersey, ao narrar a experiência de seis sobreviventes da explosão de 1945, transforma-se em um alerta mundial sobre os perigos do nuclear. Para mim, esta é a primeira grande reportagem do jornalismo ambiental moderno. O compromisso com a vida perpassa toda a narrativa. $O$ ambiental está além do científico. (...)O jornalismo ambiental não nega a ciência, mas também olha para outras questões (Belmonte, 2004: 3).

Segundo essa visão de uma cobertura desorganizada e pontual, alguns dos profissionais enquadram o jornalismo ambiental em uma espécie distinta do jornalismo científico, que, historicamente, é uma cobertura mais apurada e profissionalmente mais correta. Porém, existe uma corrente oposta que defende uma aproximação do jornalismo científico e de meio ambiente.

Tomemos como exemplo o caso do aquecimento global. As mudanças na composição da atmosfera são uma alteração de seus componentes químicos; o aumento da temperatura é assunto para medições de meteorologistas; o impacto na biodiversidade é tema de biólogo; ou seja, todos os ramos da ciência, que nos remete o problema à uma questão científica aliada à área ambiental.

Essas características e temas são comuns e, para cobri-las, as fontes e as soluções são ligadas à ciência.

Victor Bachetta (2002) afirma que o jornalismo ambiental é um ramo do jornalismo científico, por tratar de fenômenos e problemas da natureza, incluindo os seres humanos, e que deve apelar às interpretações físicas, químicas e biológicas, etc., existentes na atualidade. O jornalista tem de facilitar aos leitores esses enfoques e demonstrar que esse não é único. Com a evolução e organização do movimento ambientalista e a gradativa 
adaptação dos agentes econômicos aos novos tempos de tratados e convenções internacionais, tecnologias limpas, certificações, reciclagem, gestão ambiental e posturas "ecologicamente corretas", também muda o tom do jornalismo ambiental, que tende a se aproximar mais do jornalismo científico, garante Jonh (1997). Segundo a autora, a mídia ambiental passa a ser um termômetro importante, a ser consultado antes da tomada de decisões e até mesmo capaz de mudar o rumo de algumas delas.

O que Jonh (1997) indica é que a organização, mais comum ao jornalismo científico, bem como uma cobertura complexa e maior rigor na apuração e produção, aproximam as duas especializações, classificando o jornalismo ambiental como subárea do jornalismo científico, e, indiretamente, confere à profissão maior credibilidade entre os pares.

Bueno (2007) defende que, para que essa aproximação ocorra, as matérias devem conter algumas características durante a produção como: militância, compromisso, capacitação, ética e profissionalismo. O autor, que também considera o jornalismo ambiental como subárea do científico, entretanto como uma área ainda carente de conceituação, ressalta:

O jornalismo ambiental anseia por um conceito que extrapole o do jornalismo científico tradicional (comprometido com uma parcela significativa da comunidade científica que tem privilegiado a continuidade de suas pesquisas, sem contextualizar suas repercussões) ( Bueno, 2007:35).

\subsection{A Construção do Real - jornalismo e divulgação científica}

As constantes citações dos comunicadores e dos profissionais da mídia sempre confundem a prática, não fazendo a diferenciação entre "Divulgação Científica" e “Jornalismo Científico". Neste trabalho, faz-se necessário delimitar o campo de ação do jornalismo de ciência, para posteriormente analisar o conteúdo dessa editoria, visto que diversos autores aproximam a cobertura ambiental à científica.

Divulgação Científica e Jornalismo Científico não são a mesma coisa, embora estejam muito próximas. Ambos se destinam ao chamado público, com a intenção de democratizar as informações (pesquisas, inovações, conceitos de ciência e tecnologia), mas a primeira não é jornalismo. É o caso tanto dos fascículos, como de uma série de palestras que traduz em linguagem adequada a ciência e a tecnologia para o cidadão comum, esses produtos não se enquadram dentre os gêneros do Jornalismo. 
Bueno (1984), por exemplo, propõe a diferenciação entre divulgação e disseminação científica, por meio do jornalismo, atribuindo à divulgação a função de transferência de informações científicas e tecnológicas, transcritas em códigos especializados, a um público seleto, formado por especialistas.

Assim define Oliveira o que é Jornalismo Científico e Divulgação Científica:

Enquanto o cientista produz trabalhos dirigidos a um grupo de leitores científico, restrito e especializado, o jornalista almeja atingir o grande público. A redação do texto científico segue normas rígidas de padronização e normatização universais, além de ser mais árida, desprovida de atrativos. A escrita jornalística, rápida e efêmera. $O$ trabalho científico normalmente encontra amplos espaços para publicações nas revistas especializadas, permitindo linguagem prolixa, enquanto o texto jornalístico esbarra em espaços cada vez mais restritos, portanto deve ser sintético (OLIVEIRA, 2002: 43).

O que é possível verificar, diante desses dois autores, é que a divulgação faz-se por meio dos textos e todas as formas de comunicação das pesquisas e projetos; e que não tem o compromisso de traduzir para as pessoas leigas, cientificamente, o conteúdo dos projetos e pesquisas, mas que as funções são semelhantes, difundindo o conhecimento obtido até aquele momento sobre dada pesquisa ou trabalho.

Do outro lado, o jornalismo científico é uma maneira de tradução desses trabalhos para o grande público, com todos os atrativos de um texto característico da profissão, mas também com o objetivo de transmitir o conhecimento e informar sobre trabalhos e descobertas que podem afetar diariamente o cotidiano da população.

Outra diferença importante a destacar é que no campo da Divulgação pode haver diversas maneiras e modalidades para disseminar o conhecimento, desde uma conversa informal, literatura, filmes, palestras e artigos jornalísticos; enquanto no Jornalismo Científico as matérias obedecem aos processos e técnicas comuns à prática jornalística.

Essa definição, diante da complexidade de divulgação da ciência, ainda não parece suficiente. Outra vertente de pesquisadores conceitua a prática na linguagem, o que indica que a divulgação científica é um método de recodificação da linguagem científica, como meio de favorecer a uma camada restrita a tornar-se inteligível para um público não especializado (Destácio apud Kreinz, 2004). 
Para Gonçalves (1998;78), o objetivo da divulgação científica é levar ao grande público notícias e interpretações do progresso que uma pesquisa vai tomando, como as observações que procuram familiarizar esse público com a natureza da ciência e a vida dos cientistas. E ganhou a expansão em muitos países, não apenas na imprensa, mas sob as mais diversas formas, como livros e outros meios de comunicação de massa.

Para uma busca do que é e de como nasceu a divulgação científica, José Reis retoma o trabalho dos sofistas:

O que nenhum outro povo do Mediterrâneo jamais aprendera, isto é, que o pensamento é, por si só, uma das maiores forças da vida humana. Dir-se-á que aqueles sofistas debatedores não ensinavam especificamente a ciência, mas a arte de pensar e duvidar. O que a nosso ver os aproxima dos modernos divulgadores é o empenho em mobilizar na população o conhecimento, qualquer que seja ele. (Reis, 2006:1)

Podemos concluir que a tarefa da divulgação científica é a tentativa de familiarizar a população com um problema, ou uma descoberta, a partir de uma empresa ou instituição acadêmica que realiza uma investigação científica. Se bem que ambos os casos tratam da produção de informação, e a diferença, segundo Bachetta (2000:2), que ainda afirma: "entre a divulgação científica e o jornalismo é o sentido crítico, que dá enfoques dentro e fora da ciência consagrada”.

A divulgação científica aproxima o cidadão comum dos benefícios que ele tem - o direito de reivindicar, para a melhoria e o bem estar social. Ela pode contribuir também para uma visão mais clara da realidade, ao se contrapor aos aspectos característicos de uma cultura pouco desenvolvida, ainda contaminada por superstições e crenças que impedem as pessoas de localizar com clareza as verdadeiras causas e os efeitos dos problemas que enfrentam na vida cotidiana Oliveira (2002).

A divulgação científica radicou-se como propósito de levar ao grande público, além da notícia e interpretação dos progressos da ciência, as observações que procuram familiarizar esse público com a natureza do trabalho da ciência e a vida dos cientistas. Assim conceituada, ela ganhou grande expansão em muitos países, não só na imprensa, mas sob forma de livros e, mais refinadamente, em outros meios de comunicação de massa (Reis, 2006). 
A condição de gênero jornalístico implica que o jornalismo científico atua como qualquer outra área da profissão, em essência, em conformidade com os procedimentos rotineiros de qualquer outra expressão jornalística. $\mathrm{O}$ contato com as fontes, a obtenção e checagem das informações e a formatação do texto noticioso, com o emprego de um vocabulário simples, de fácil compreensão, são algumas das tarefas do jornalista, qualquer que seja a especialidade.

Tais elementos delimitam o que aqui se entende por jornalismo científico: um produto elaborado pela mídia a partir de certas regras rotineiras do jornalismo em geral, que trata de temas complexos de ciência e tecnologia e que se apresenta, no plano lingüístico, por uma operação que torna fluída a leitura e o entendimento do texto noticioso por parte de um público não especializado.

Então, o Jornalismo Científico deve ser em primeiro lugar Jornalismo, depende estritamente de alguns parâmetros que tipificam o jornalismo, como a periodicidade, a atualidade e a difusão coletiva. O Jornalismo, enquanto atividade profissional, modalidade de discurso e forma de produção, tem características próprias, gêneros próprios e assim por diante.

O jornalismo científico pode ser uma excelente ferramenta para a divulgação e o conhecimento do público, diante das questões científicas, desde que observadas as questões éticas do jornalismo. Oliveira (2002) ressalta que o casamento perfeito entre a ciência e o jornalismo ocorre quando a primeira, que busca o conhecimento do real, encontra um tradutor fiel, ou seja, jornalismo que usa a informação para interpretar o conhecimento da realidade.

Para demonstrar esse acordo entre as partes e como o jornalismo científico deve ser, a autora utiliza um trecho de uma matéria assinada por Martin H. Teicher:

Em 1994, a polícia de Boston chocou-se ao descobrir um menino de quatro anos de idade, desnutrido e trancado num apartamento imundo de Roxbury, onde vivia em condições pavorosas. Pior, as mãozinhas da criança haviam sido horrivelmente queimadas. Soube-se que a mãe, viciada em drogas, tinha posto as mãos do menino sob a torneira de água fervente para castigá-lo por ter consumido a comida de seu namorado. A criança ferida não tivera nenhum tipo de assistência médica. A história perturbadora chegou rapidamente às manchetes. Adotado, o menino recebeu enxertos de pele para ajudar as mãos machucadas a recuperar suas funções. Mas, embora as feridas físicas da vítima tenham sido tratadas, descobertas recentes indicam que ferimentos inflingidos a sua mente em desenvolvimento podem nunca cicatrizar de todo. Oliveira, (2002). 
Para oferecer uma versão conclusiva sobre o conceito, Bueno (1984) oferece uma possível definição sintética de jornalismo científico:

Um caso particular de divulgação científica e [que] refere-se a processos, estratégias, técnicas e mecanismos para a veiculação de fatos que se situam no campo da ciência e da tecnologia. Desempenha funções econômicas, políticoideológicas e sócio-culturais importantes e viabiliza-se, na prática, através de um conjunto diversificado de gêneros jornalísticos. (Bueno 1984:11)

\subsection{Os Desafios da Imprensa Científica e Ambiental}

A divulgação da ciência é também uma forma de educar e posicionar a população para que opine diante dos fatos. De acordo com o Instituto Ethos (2002), "a importância das informações pode ser avaliada por diversas perspectivas, mas, em qualquer sistema, a perspectiva essencial é a do usuário da informação." O principal papel da informação é gerar subsídios para a tomada de decisões, e as personagens principais deste processo são as pessoas.

Bueno (2007:35) sustenta a idéia de que "o jornalismo ambiental é, antes de tudo, jornalismo (que é o substantivo, o núcleo da expressão) e deve ter compromisso com o interesse público, com a democratização do conhecimento, com a ampliação do debate".

Graça Caldas (2000:1) aponta que o jornalista científico não deve se limitar à função de mero "tradutor" da fala do cientista e divulgador de sua produção, por mais relevante que seja. E define a importância do jornalista científico como "a função estratégica da C\&T, o impacto da produção científica e tecnológica sobre o meio ambiente e o bem-estar da sociedade em geral exigem uma mudança substancial na relação entre jornalista, cientista e sociedade".

O que fica claro em todos esses teóricos é que a preocupação em conscientizar e educar as pessoas deve ser o objetivo do jornalismo ambiental. E que a imprensa, diante dessa perspectiva, acaba se transformando em uma ferramenta útil na manutenção da democracia e na formação e disseminação do conceito de cidadania.

Bachetta (2000) argumenta que os meios ambientais devem ser educativos ou pedagógicos, e diz ser importante que, diante da situação dos países de nossa região ou continente, que não possuem a educação básica e não têm, conseqüentemente, a preparação suficiente para compreender os aspectos técnicos diversos do problema, os jornalistas não podem subestimá-los. 
Entretanto, o mesmo autor sugere que é relevante que os meios educativos não sejam confundidos com formulários do paternalismo informativo, que são caracterizados por darem os fatos digeridos, sem o espírito crítico; que boa parte da população não teve o acesso à instrução formal pode e deve perfeitamente compreender o problema e elaborar sua própria opinião.

Belmonte também apóia essa idéia e diz que "o jornalismo pode ser uma ferramenta de educação ambiental e que informações de qualidade são necessárias no processo educativo". Segundo o autor, "as informações publicadas na imprensa formam pontos de vista sobre a realidade", o que nos leva a pensar a força da prática do jornalismo e a influência na vida das pessoas.

Conforme nos indica Bueno (2007), essa militância é ingrediente fundamental no perfil de um jornalista responsável e ético. Mas o que seria essa militância?

Podemos aqui definir que o jornalista científico militante está interessado não apenas na grande descoberta, mas no impacto que ela possa acarretar para a sociedade. Ele contextualiza, ele busca perceber além do fato em si e não adota, nunca, uma posição ingênua. É cético por excelência, porque admite que não existe verdade imutável, como tem aprendido, ao longo da sua vida, com a história da ciência.

Essa questão do posicionamento diante das questões ambientais transmite equivocadamente a imagem de ativista radical. Isso não é absorvido pelos leitores, devido a diversos deslizes de vários defensores do meio ambiente.

Bueno (2007) descreve que o jornalismo ambiental deve propor-se política, social e culturalmente engajado, porque só desta forma conseguirá encontrar forças para resistir às investidas e pressões de governos, empresas e até de universidades e institutos de pesquisa, muitos deles patrocinados ou reféns dos grandes interesses.

Belmonte (1997) ressalta que, se fossem publicados menos desastres e previsões cientificas negativas, e mais dicas práticas para o cotidiano das pessoas, o jornalismo ambiental alcançaria o real objetivo de ambos os lados: responsabilidade social do jornalista e conscientização do ambientalista, sem ser radical ou extremista.

Toda a imprensa é militante. A maioria se diz militante da neutralidade e se apresenta como representante legítima de algo que chama de imparcialidade. Entre esta maioria estão os que militam contra o governo e os que militam a favor do governo. Têm aqueles que militam pelo desenvolvimento sem limites e os que 
militam pela ciência e pelo método cartesiano. E há ainda um grupo de criminosos que milita em causa própria no jornalismo diário (Belmonte, 2004:4).

Bueno (2007) descreve essa militância como o compromisso primeiro e inadiável dos jornalistas com a conscientização, com a mobilização de braços e mentes, com a superação das desigualdades, com a denúncia dos grandes interesses. Isso significa repudiar a neutralidade, tomar partido, investigar as causas e consequiências da ação dos grupos econômicos que degradam o meio ambiente.

Consiste, segundo o autor, sobretudo, em defender, com coragem, a necessidade premente de aumento da qualidade de vida dos cidadãos.

O que nos leva a crer que a militância em jornalismo ambiental implica dominar os conceitos básicos jornalísticos, e estar comprometido com uma perspectiva crítica, contextualizando as questões ambientais, e politizar o debate.

Bueno (2007) ressalta que alguns jornalistas provavelmente confundem militância com filiação partidária e, querendo se afastar das práticas dos partidos brasileiros, optam por não assumir essa condição. O autor ainda diz que:

Ser militante não significa estar disposto a pegar em armas para fazer valer, a qualquer custo, as nossas convicções.Ser militante significa apenas defender, com coragem, as nossas posições, ainda que elas possam nos criar embaraços junto a patrões ou colegas da redação. O não militante está sempre disposto a abdicar das suas posições para não perder o emprego, para conseguir clientes, para ser aceito em um grupo do qual possa extrair vantagens. O não militante tem uma ética muito particular: busca estar de bem com a maioria e, especialmente, com os que detêm o poder. (Bueno 2007:35)

Esse jornalista ético e profissional é aquele que consegue educar, mobilizar e sensibilizar quanto aos problemas da sociedade, trazendo para o cotidiano as soluções científicas e tecnológicas, capazes de ajudar e de resolver os problemas da população, educando e formando cidadãos críticos capazes de posicionar-se diante dos problemas do dia-a-dia. 


\section{A COBERTURA DA IMPRENSA SOBRE A QUESTÃO NUCLEAR EM 2007}

Segundo os manuais de redação dos jornais Folha de S.Paulo e O Estado de S.Paulo, base para a maioria dos jornais brasileiros, as fontes são classificadas por nível hierárquico de confiabilidade. Cabe a cada jornalista determinar a hierarquia de suas fontes de informação, no entanto, sustentado em bom senso e histórico das fontes. Neste caso, os jornais dividem as fontes em quatro categorias: fonte tipo zero, tipo um, tipo dois e tipo três. Cada uma dessas fontes demanda do jornalista procedimentos diferentes para a preparação e finalização do texto:

1. Fonte tipo zero - escrita e com tradição de exatidão, ou gravada sem deixar margem a dúvida: enciclopédias renomadas, documentos emitidos por instituição de credibilidade, videoteipes. Em geral, a fonte de tipo zero prescinde de cruzamento. Para não repetir erros já publicados, evitar ter um periódico do tipo jornal ou revista como única fonte para uma informação.

2. Fonte tipo um - é a mais confiável, nos casos em que a fonte é uma pessoa. A fonte de tipo um tem histórico de confiabilidade - as informações que passa sempre se mostram corretas. Fala com conhecimento de causa, está muito próxima do fato que relata e não tem interesses imediatos na sua divulgação. Embora o cruzamento de informação seja sempre recomendável, admite-se que informações vindas de uma fonte tipo um sejam publicadas sem checagem com outra fonte.

3. Fonte tipo dois - têm todos os atributos da fonte tipo um menos o histórico de confiabilidade. Toda informação de fonte dois deve ser cruzada com pelo menos mais uma fonte (do tipo um ou dois), antes de publicada.

4. Fonte tipo três - a de menor confiabilidade. É bem informada, mas tem interesses (políticos, econômicos, etc.) que tornam suas informações nitidamente menos confiáveis. Há dois caminhos para a informação de fonte tipo três: funcionar como simples ponto de partida para o trabalho jornalístico ou, na impossibilidade de cruzamento com outras fontes, ser publicada em coluna de bastidores, com a indicação explícita de que ainda se trata de rumor, informação não-confirmada. 
Os manuais chamam ainda a atenção para o fato de, diante de mudanças no cenário político e no nível de relacionamento entre fonte e jornalista, haver variação na classificação dessas fontes. Outro registro importante refere-se à orientação para que o jornalista não entenda a classificação como uma "camisa-de-força". Isso significa que uma fonte zero pode disseminar equívocos ou rumores e a fonte três, informações precisas e confiáveis.

No jornalismo especializado, por exemplo, as fontes de informação são divididas em quatro categorias: a dos especialistas, usuários, autoridades e dos protagonistas. A categoria denominada 'especialistas' é aquela formada por cientistas, técnicos e demais conhecedores do assunto abordado na matéria. A categoria 'usuários' refere-se a pessoas, comunidades e demais grupos direta ou indiretamente beneficiados ou atingidos pelo fenômeno abordado na matéria. Já a categoria 'autoridades' pode ter como fonte o presidente da república, ministros, secretários municipais e estaduais e presidentes de instituições públicas e órgãos reguladores. A categoria 'protagonistas' é a dos agentes da matéria, ou seja, aqueles que deram origem ao fato jornalístico.

No entanto, essa sociedade midiática e complexa, com fluxo acentuado de informação e novas tecnologias de comunicação, demanda uma revisão dessa categorização clássica das fontes de informação.

Nesta pesquisa, cuja análise da cobertura jornalística sobre a energia nuclear está sustentada nos preceitos da escola pós-marxista do discurso, concebemos uma classificação das fontes por grupos direta e indiretamente envolvidos com a questão nuclear. Assim, a Tabela 5 revela as cinco categorias de fontes utilizadas neste estudo. 
Tabela 5 - Classificação das fontes de informação

\begin{tabular}{|c|c|}
\hline \multicolumn{2}{|r|}{ Classificação das fontes de informação } \\
\hline Categoria & Instituições pessoas \\
\hline Protagonistas & $\begin{array}{l}\text { - } \text { Greenpeace } \\
\text { - Ascende Brasil } \\
\text { - Jornalistas }\end{array}$ \\
\hline Autoridades & $\begin{array}{l}\text { - } \quad \text { Presidente da República } \\
\text { - } \quad \text { Ministério de Minas e Energia } \\
\text { - } \quad \text { Ministro do Meio Ambiente } \\
\text { - } \quad \text { Presidente da CNEN }\end{array}$ \\
\hline Usuários & $\begin{array}{l}\text { - Moradores de regiões direta ou indiretamente beneficiadas ou atingidas pela } \\
\text { questão nuclear } \\
\text { - Associações de moradores }\end{array}$ \\
\hline Especialistas & $\begin{array}{ll}\text { - } & \text { Físicos } \\
\text { - Geólogos } \\
\text { - } & \text { Climatologistas } \\
\text { - } & \text { Economistas } \\
\end{array}$ \\
\hline Empresários & $\begin{array}{l}\text { - Presidentes e diretores das empresas detentoras das tecnologias de geração ou } \\
\text { disposição de rejeitos nucleares, construtoras de usinas etc. }\end{array}$ \\
\hline
\end{tabular}

Fonte: o próprio autor

Como recorremos à escola pós-marxista do discurso, que entende o discurso como a concretização do encontro entre a ideologia e a fala, a tabela acima e a sua respectiva análise sugerem que a fonte seja, basicamente, sinônimo de um dado discurso. Por exemplo, quando identificamos uma ONG ambientalista como fonte de informação, já é possível saber que o discurso dessa fonte, no caso da energia nuclear, é desfavorável a ela. No caso das autoridades, o discurso esperado, contrariamente ao das ONGs, seria o de posicionar-se favoravelmente à energia nuclear.

\subsection{Coleta de Material Jornalístico}

As reportagens veiculadas na mídia impressa, cujo tema principal da matéria se referia à energia nuclear, foram selecionadas no clipping da CETESB, cobrindo o período compreendido entre fevereiro de 2007 a fevereiro de 2008. Foram encontradas 172 matérias, distribuídas em vinte e dois veículos de comunicação, sendo dezessete jornais e quatro revistas.

Um quadro resumido do material coletado, destacando o veículo de mídia impressa, o título da matéria, o tipo de abordagem e a fonte geradora da notícia, é apresentado na Tabela 6. Cópias das reportagens estão reproduzidas no Anexo. 
Tabela 6 - Notícias envolvendo a energia nuclear

\begin{tabular}{|c|c|c|c|c|c|}
\hline Data & Veículo & Título & Abordag. & Instituição & Fonte \\
\hline $1 / 2 / 2007$ & O Empreiteiro & $\begin{array}{l}\text { Aquecimento global resgata energia } \\
\text { nuclear e incentiva fontes limpas }\end{array}$ & Mista & Jornalista & Protagonista \\
\hline $2 / 2 / 2007$ & Gazeta Mercantil & Risco para usinas nucleares & Negativa & Keith Fenwick, analista do Met Office & Especialista \\
\hline \multirow[t]{3}{*}{$4 / 2 / 2007$} & \multirow[t]{3}{*}{ O Estado de S. Paulo } & \multirow[t]{3}{*}{$\begin{array}{l}\text { Ministro quer que Brasil volte a } \\
\text { investir em energia nuclear }\end{array}$} & \multirow[t]{3}{*}{ Mista } & $\begin{array}{l}\text { Sérgio Rezende, Ministro da Ciência e } \\
\text { Tecnologia }\end{array}$ & Autoridade \\
\hline & & & & $\begin{array}{l}\text { Cláudio Langone, secretário executivo do Meio } \\
\text { Ambiente }\end{array}$ & Autoridade \\
\hline & & & & Greenpeace & Protagonista \\
\hline \multirow[t]{2}{*}{$5 / 2 / 2007$} & \multirow[t]{2}{*}{ Gazeta Mercantil } & \multirow[t]{2}{*}{ Greenpeace propõe o fim dos fósseis } & \multirow[t]{2}{*}{ Negativa } & Marcelo Furtado, Greenpeace & Protagonista \\
\hline & & & & André Gimenes, pesquisador da USP & Especialista \\
\hline $6 / 2 / 2007$ & Valor Econômico & $\begin{array}{l}\text { Leilões dão prioridade a fontes } \\
\text { poluentes }\end{array}$ & Negativa & $\begin{array}{l}\text { Maurício Tolmasquim, presidente da EPE } \\
\text { (Empresa de Pesquisa Energética) }\end{array}$ & Autoridade \\
\hline
\end{tabular}




\begin{tabular}{|c|c|c|c|c|c|}
\hline $7 / 2 / 2007$ & O Estado de S. Paulo & "Energia Nuclear é a melhor opção" & Positiva & James Lovelock, pesquisador do Green College & Especialista \\
\hline $10 / 2 / 2007$ & O Estado de S. Paulo & A Amazônia e a energia nuclear & Positiva & $\begin{array}{l}\text { Sandra Cavalcanti, professora, jornalista e ex- } \\
\text { deputada }\end{array}$ & Protagonista \\
\hline $12 / 2 / 2007$ & O Estado de S. Paulo & $\begin{array}{l}\text { Ambientalistas decidem rever } \\
\text { questão nuclear }\end{array}$ & Mista & $\begin{array}{l}\text { Sarney Filho deputado (PV-MA), José Carlos } \\
\text { Aleluia deputado (PFL-BA), Rui de Goes, } \\
\text { diretor de qualidade ambiental do Ministério do } \\
\text { Meio Ambiente, }\end{array}$ & Autoridade \\
\hline & & & & $\begin{array}{l}\text { Sérgio Rezende, Ministro de Ciência e } \\
\text { Tecnologia }\end{array}$ & Autoridade \\
\hline $13 / 2 / 2007$ & O Estado de S. Paulo & Decisão sobre Angra 3 não tem prazo & Mista & $\begin{array}{l}\text { Dilma Rousseff, ministra da Casa Civil, } \\
\text { Marcelo Furtado, Greenpeace }\end{array}$ & Autoridade \\
\hline
\end{tabular}




\begin{tabular}{|c|c|c|c|c|c|}
\hline \multirow{2}{*}{\multicolumn{2}{|c|}{ 13/2/2007|O Estado de S. Paulo }} & \multirow[t]{2}{*}{$\begin{array}{l}\text { Expansão da energia nuclear e } \\
\text { Guimarães exige } 24 \text { bilhões }\end{array}$} & \multirow[t]{2}{*}{ Mista } & $\begin{array}{l}\text { Luiz Pinguelli Rosa, físico UFRJ e ex- } \\
\text { presidente da Eletrobrás }\end{array}$ & Especialista \\
\hline & & & & $\begin{array}{l}\text { Leonam dos Santos, assistente da presidência } \\
\text { da Eletronuclear }\end{array}$ & Autoridade \\
\hline $15 / 2 / 2007$ & Correio Braziliense & O PAC e o meio ambiente & Negativa & $\begin{array}{l}\text { José Goldemberg, professor do Instituto de } \\
\text { Eletrotécnica e Energia da USP }\end{array}$ & Especialista \\
\hline $15 / 2 / 2007$ & O Estado de S. Paulo & Brasil tem urânio para 80 anos & Positiva & Odair Gonçalves, presidente da CNEN & Autoridade \\
\hline $16 / 2 / 2007$ & Valor Econômico & A polêmica de Angra 3 revive & Negativa & Luis Pinguelli Rosa, engenharia da UFRJ & Especialista \\
\hline & & & & Guilherme Leonardi, Greenpeace & Protagonista \\
\hline $23 / 2 / 2007$ & O Estado de S. Paulo & O Clima esquentou mesmo. E agora? & Negativa & Washington Novaes & Protagonista \\
\hline
\end{tabular}




\begin{tabular}{|c|c|c|c|c|c|}
\hline $5 / 3 / 2007$ & $7 \longdiv { \text { Gazeta Mercantil } }$ & Usina nuclear no S. Francisco & Negativa & $\begin{array}{l}\text { Humberto Viana Guimarães, consultor de } \\
\text { Energia e Concreto - Salvador (BA) }\end{array}$ & Empresário \\
\hline $6 / 3 / 2007$ & 7 O Estado de S. Paulo & $\begin{array}{l}\text { Ação pede instalação de depósito em } \\
\text { Angra }\end{array}$ & Positiva & Eletronuclear & Autoridade \\
\hline $9 / 3 / 2007$ & 7 O Estado de S. Paulo & Europa, petróleo e energia nuclear & Negativa & Gilles Lapouge, correspondente em Paris & Protagonista \\
\hline $4 / 4 / 2007$ & 7 O Estado de S. Paulo & Discutir Angra 3, só em junho & Positiva & $\begin{array}{l}\text { Sérgio Rezende, Ministro de Ciência e } \\
\text { Tecnologia }\end{array}$ & Autoridade \\
\hline $10 / 4 / 2007$ & $7 \longdiv { O }$ Estado de S. Paulo & O fantasma do apagão está de volta & Positiva & $\begin{array}{l}\text { Oscar Marcondes Pimentel, pres. da Câmara } \\
\text { para Assuntos de Energia da Fecomércio }\end{array}$ & Autoridade \\
\hline $11 / 4 / 2007$ & $7 \longdiv { O }$ Estado de S. Paulo & $\begin{array}{l}\text { Cientistas tiveram problemas com } \\
\text { primeiras centrífugas }\end{array}$ & Negativa & $\begin{array}{l}\text { Mark Fitzpatrick, Instituto Internacional para } \\
\text { Estudos Estratégicos de Londres }\end{array}$ & Especialista \\
\hline
\end{tabular}




\begin{tabular}{|c|c|c|c|c|c|}
\hline $11 / 4 / 2007$ & Folha de S. Paulo & $\begin{array}{l}\text { Rússia mostra ceticismo sobre } \\
\text { avanço nuclear }\end{array}$ & Mista & $\begin{array}{l}\text { Gholam Reza Aghazadeh, presidente da } \\
\text { Organização de Energia Atômica do Irã }\end{array}$ & Autoridade \\
\hline $13 / 4 / 2007$ & Folha de S. Paulo & O novo momento da energia nuclear & Positiva & Luiz Sérgio, deputado federal PT-RJ & Autoridade \\
\hline $13 / 4 / 2007$ & $\mathrm{DCI}$ & Eletricidade cara e escassa & Mista & Luiz Gonzaga Bertelli, diretor do Deinfra & Autoridade \\
\hline $13 / 4 / 2007$ & O Globo & A opção brasileira & Mista & $\begin{array}{l}\text { Marco Aurélio Garcia, assessor do Presidente } \\
\text { da República }\end{array}$ & Autoridade \\
\hline $19 / 4 / 2007$ & Folha de S. Paulo & Nuclear & Positiva & Luiz Sérgio deputado federal PT-RJ & Autoridade \\
\hline $27 / 4 / 2007$ & Folha de S. Paulo & $\begin{array}{l}\text { País não precisa de nova usina, diz } \\
\text { professor }\end{array}$ & Negativa & Luiz Pinguelli Rosa, da UFRJ & Especialista \\
\hline \multirow[t]{2}{*}{$27 / 4 / 2007$} & \multirow[t]{2}{*}{ Folha de S. Paulo } & \multirow[t]{2}{*}{$\begin{array}{l}\text { Marina critica termelétricas, Angra } 3 \\
\text { e colegas de governo }\end{array}$} & \multirow[t]{2}{*}{ Negativa } & Marina Silva, Ministra do Meio Ambiente & Autoridade \\
\hline & & & & $\begin{array}{l}\text { Luiz Inácio Lula da Silva, presidente da } \\
\text { República }\end{array}$ & Autoridade \\
\hline $4 / 5 / 2007$ & O Estado de S. Paulo & $\begin{array}{l}\text { Lula fala em optar por usinas } \\
\text { nucleares }\end{array}$ & Positiva & Luiz Inácio Lula da Silva, pres. da República & Autoridade \\
\hline
\end{tabular}




\begin{tabular}{|c|c|c|c|c|c|}
\hline \multirow{3}{*}{\multicolumn{2}{|c|}{\begin{tabular}{l|l} 
4/5/2007|Folha de S. Paulo \\
F
\end{tabular}}} & \multirow[t]{3}{*}{$\begin{array}{l}\text { Opção a hidrelétrica é usina nuclear, } \\
\text { diz Lula }\end{array}$} & \multirow[t]{3}{*}{ Mista } & Luiz Inácio Lula da Silva, pres. da República & Autoridade \\
\hline & & & & Marina Silva, Ministra do Meio Ambiente & Autoridade \\
\hline & & & & Roger Agnelli, presidente da Vale & Empresário \\
\hline $4 / 5 / 2007$ & $\begin{array}{l}\text { Diário do Grande } \\
\text { ABC }\end{array}$ & $\begin{array}{l}\text { Lula ameaça ambientalistas com } \\
\text { energia nuclear }\end{array}$ & Positiva & Luiz Inácio Lula da Silva, pres. da República & Autoridade \\
\hline $4 / 5 / 2007$ & $\mathrm{DCI}$ & Energia suja versus energia limpa & Negativa & Antonio Delfim Netto, professor da FEA/USP & Especialista \\
\hline $4 / 5 / 2007$ & Valor Econômico & $\begin{array}{l}\text { Lula usa energia nuclear para } \\
\text { pressionar por hidrelétricas }\end{array}$ & Positiva & Luiz Inácio Lula da Silva, pres. da República & Autoridade \\
\hline & & & & Roger Agnelli, presidente da Vale do Rio Doce & Empresário \\
\hline $5 / 5 / 2007$ & Diário de São Paulo & $\begin{array}{l}\text { ONU sugere energia nuclear contra } \\
\text { aquecimento global }\end{array}$ & Positiva & Bert Mertz, co-presidente do grupo do IPCC & Especialista \\
\hline $5 / 5 / 2007$ & $\begin{array}{l}\text { Diário do Grande } \\
\text { ABC }\end{array}$ & $\begin{array}{l}\text { Mundo tem condições de reduzir o } \\
\text { aquecimento global }\end{array}$ & Positiva & Ogunlade Davidson, co-presidente do IPCC & Especialista \\
\hline $5 / 5 / 2007$ & O Estado de S. Paulo & $\begin{array}{l}\text { Brasil terá novas regras de segurança } \\
\text { nuclear }\end{array}$ & Positiva & Samuel Fayad, diretor da INB & Autoridade \\
\hline
\end{tabular}




\begin{tabular}{|c|c|c|c|c|c|}
\hline $6 / 5 / 2007$ & A Tribuna & Energia suja $\mathrm{x}$ energia limpa & Negativa & Antonio Delfim Netto, professor da FEA/USP & Especialista \\
\hline $6 / 5 / 2007$ & $\begin{array}{l}\text { Diário do Grande } \\
\mathrm{ABC}\end{array}$ & A volta do Brasil atômico & Mista & Carlos Brickmann & Protagonista \\
\hline $7 / 5 / 2007$ & Veja & Sim, ainda podemos limpar a sujeira & Positiva & IPCC & Especialista \\
\hline $12 / 6 / 2007$ & Folha de S. Paulo & $\begin{array}{l}\text { Lula defende submarino com reator } \\
\text { nuclear }\end{array}$ & Positiva & Luiz Inácio Lula da Silva, pres. da República & Autoridade \\
\hline $12 / 6 / 2007$ & O Estado de S. Paulo & $\begin{array}{l}\text { Lula defende projeto nuclear da força } \\
\text { naval }\end{array}$ & Positiva & $\begin{array}{l}\text { Júlio Soares de Moura Neto, almirante da } \\
\text { Marinha }\end{array}$ & Autoridade \\
\hline $13 / 6 / 2007$ & Gazeta Mercantil & A questão dos rejeitos nucleares & Positiva & Glória Alvarez, assessora da pres. Eletronuclear & Autoridade \\
\hline $13 / 6 / 2007$ & O Estado de S. Paulo & $\begin{array}{l}\text { Relatório constata avanço nuclear do } \\
\text { país }\end{array}$ & Negativa & Jornalista & Protagonista \\
\hline $13 / 6 / 2007$ & Jornal do Brasil & Urânio virou um grande negócio & Positiva & Luiz Inácio Lula da Silva, pres. da República & Autoridade \\
\hline $14 / 6 / 2007$ & O Estado de S. Paulo & $\begin{array}{l}\text { Não há energia para o Brasil crescer } \\
\text { mais de } 4 \% \text { ao ano }\end{array}$ & Positiva & Maurício Tolmasquim, EPE & Autoridade \\
\hline $14 / 6 / 2007$ & Valor Econômico & $\begin{array}{l}\text { Depósito para armazenar lixo nuclear } \\
\text { será criado com } 2 \% \text { de recitas de } \\
\text { usinas }\end{array}$ & Positiva & Othon Pinheiro da Silva, Eletronuclear & Autoridade \\
\hline $14 / 6 / 2007$ & DCI & $\begin{array}{l}\text { Plano Nuclear privilegia tecnologia } \\
\text { brasileira }\end{array}$ & Positiva & Aquilino Senra, professor & Autoridade \\
\hline
\end{tabular}




\begin{tabular}{|c|c|c|c|c|c|}
\hline & & & & Leonam Guimarães, técnico da Eletronuclear & Usuário \\
\hline & & & & $\begin{array}{l}\text { Sérgio Rezende, Ministro de Ciência e } \\
\text { Tecnologia }\end{array}$ & Autoridade \\
\hline & & & & Othon Pinheiro, pres. Eletronuclear & Autoridade \\
\hline $14 / 6 / 2007$ & DCI & $\begin{array}{l}\text { Urânio é alvo de interesse no } \\
\text { mercado interno }\end{array}$ & Positiva & $\begin{array}{l}\text { Aquilino Senra, professor do Programa de } \\
\text { Engenharia Nuclear da Coppe/UFRJ }\end{array}$ & Especialista \\
\hline $14 / 6 / 2007$ & O Estado de S. Paulo & Nordeste deverá ter usina nuclear & Positiva & Othon Pinheiro, pres. Eletronuclear & Autoridade \\
\hline $15 / 6 / 2007$ & O Globo & $\begin{array}{l}\text { Lula quer construir a usina nuclear de } \\
\text { Angra } 3\end{array}$ & Positiva & Luiz Inácio Lula da Silva, pres. da República & Autoridade \\
\hline $15 / 6 / 2007$ & Folha de S. Paulo & $\begin{array}{l}\text { Lula afirma que Angra } 3 \text { será } \\
\text { concluída }\end{array}$ & Positiva & Luiz Inácio Lula da Silva, pres. da República & Autoridade \\
\hline $15 / 6 / 2007$ & Valor Econômico & Lula defende construção de Angra 3 & Positiva & Luiz Inácio Lula da Silva, pres. da República & Autoridade \\
\hline
\end{tabular}




\begin{tabular}{|c|c|c|c|c|c|}
\hline $15 / 6 / 2007$ & O Estado de S. Paulo & Lula indica que Angra 3 vai sair & Positiva & Luiz Inácio Lula da Silva, pres. da República & Autoridade \\
\hline $16 / 6 / 2007$ & Jornal do Brasil & Angra 3 recebe sinal verde & Positiva & Walter Diogo, jornalista & Protagonista \\
\hline $17 / 6 / 2007$ & O Estado de S. Paulo & $\begin{array}{l}\text { País prepara salto de eficiência na } \\
\text { produção de urânio enriquecido }\end{array}$ & Positiva & $\begin{array}{l}\text { Carlos Bezerril, diretor do Centro Tecnológico } \\
\text { da Marinha }\end{array}$ & Autoridade \\
\hline \multirow[t]{4}{*}{$21 / 6 / 2007$} & \multirow[t]{4}{*}{ Valor Econômico } & \multirow[t]{4}{*}{$\begin{array}{l}\text { Audiência de Angra } 3 \text { mostra cidade } \\
\text { dividida }\end{array}$} & \multirow[t]{4}{*}{ Mista } & Fernando Jordão (PMDB) & Autoridade \\
\hline & & & & Ronaldo Nunes, enfermeiro & $\begin{array}{l}\text { Usuário } \\
\end{array}$ \\
\hline & & & & $\begin{array}{l}\text { Donato Borges, pres. do Sindicato da } \\
\text { Construção Civil }\end{array}$ & Usuário \\
\hline & & & & $\begin{array}{l}\text { Pedro Figueiredo, dir. de operações da } \\
\text { Eletronuclear }\end{array}$ & Usuário \\
\hline $21 / 6 / 2007$ & Gazeta Mercantil & Governo já estuda mais quatro usinas & Positiva & $\begin{array}{l}\text { Othon Luiz Pinheiro, presidente da } \\
\text { Eletronuclear }\end{array}$ & Autoridade \\
\hline $21 / 6 / 2007$ & Folha de S. Paulo & $\begin{array}{l}\text { Eletronuclear estuda erguer usinas } \\
\text { nucleares em SP }\end{array}$ & Positiva & $\begin{array}{l}\text { Othon Luiz Pinheiro, presidente da } \\
\text { Eletronuclear }\end{array}$ & Autoridade \\
\hline
\end{tabular}




\begin{tabular}{|c|c|c|c|c|c|}
\hline $21 / 6 / 2007$ & O Estado de S. Paulo & Interior de SP pode ter usina nuclear & Positiva & $\begin{array}{l}\text { Othon Luiz Pinheiro, presidente da } \\
\text { Eletronuclear }\end{array}$ & Autoridade \\
\hline $22 / 6 / 2007$ & Agora São Paulo & SP pode ter usina nuclear & Positiva & $\begin{array}{l}\text { Othon Luiz Pinheiro, presidente da } \\
\text { Eletronuclear }\end{array}$ & Autoridade \\
\hline $22 / 6 / 2007$ & Gazeta Mercantil & $\begin{array}{l}\text { Ministro: "vamos bater o martelo } \\
\text { para Angra 3" }\end{array}$ & Positiva & $\begin{array}{l}\text { Sérgio Rezende, Ministro de Ciência e } \\
\text { Tecnologia }\end{array}$ & Autoridade \\
\hline \multirow[t]{3}{*}{$25 / 6 / 2007$} & Folha de S. Paulo & $\begin{array}{l}\text { Decisão sobre usina nuclear Angra } 3 \\
\text { pode sair hoje }\end{array}$ & Mista & Maurício Tolmasquim, presidente da EPE & Autoridade \\
\hline & & & & José Goldemberg, físico nuclear & Especialista \\
\hline & & & & Claúdio Salles, do Instituto Acende Brasil & Protagonista \\
\hline $25 / 6 / 2007$ & $\mathrm{DCI}$ & $\begin{array}{l}\text { Conselho deve definir programa } \\
\text { nuclear hoje }\end{array}$ & Mista & Jornalista & Protagonista \\
\hline $24 / 6 / 2007$ & O Estado de S. Paulo & $\begin{array}{l}\text { Brasil está perto de produzir gás } \\
\text { natural }\end{array}$ & Mista & Carlos Bezerril, diretor do Centro Tecnológico & Autoridade \\
\hline $24 / 6 / 2007$ & Folha de S. Paulo & Por que Angra 3 & Mista & Jornalista & Protagonista \\
\hline
\end{tabular}




\begin{tabular}{|c|c|c|c|c|c|}
\hline $26 / 6 / 2007$ & $7 \longdiv { O }$ Estado de S. Paulo & País decide ampliar programa nuclear & Positiva & $\begin{array}{l}\text { Nelson Hubner, ministro interino de Minas e } \\
\text { Energia }\end{array}$ & Autoridade \\
\hline $26 / 6 / 2007$ & 7 O Estado de S. Paulo & $\begin{array}{l}\text { Angra } 3 \text { põe Brasil em nova onda de } \\
\text { expansão de usinas nucleares }\end{array}$ & Positiva & Miracyr Marcato, diretor do IE & Especialista \\
\hline \multirow[t]{2}{*}{$26 / 6 / 2007$} & \multirow[t]{2}{*}{ O Estado de S. Paulo } & \multirow[t]{2}{*}{$\begin{array}{l}\text { Investimentos na usina vão atingir } \\
\text { quase } \mathrm{R} \$ 8 \text { bilhões }\end{array}$} & \multirow[t]{2}{*}{ Mista } & Odair Dias Gonçalves, presidente da CNEN & Autoridade \\
\hline & & & & José Goldemberg, professor da USP & Especialista \\
\hline $26 / 6 / 2007$ & 7 O Estado de S. Paulo & País retomará construção de Angra 3 & Positiva & $\begin{array}{l}\text { Nelson Hubner, ministro interino de Minas e } \\
\text { Energia }\end{array}$ & Autoridade \\
\hline \multirow[t]{3}{*}{$26 / 6 / 2007$} & \multirow[t]{3}{*}{ Folha de S. Paulo } & \multirow[t]{3}{*}{$\begin{array}{l}\text { Conselho aprova retomada da } \\
\text { construção de Angra } 3\end{array}$} & \multirow[t]{3}{*}{ Mista } & $\begin{array}{l}\text { Nelson Hubner, ministro interino de Minas e } \\
\text { Energia }\end{array}$ & Autoridade \\
\hline & & & & Guilherme Leonardi, do Greenpeace & Protagonista \\
\hline & & & & Paulo Godoy, presidente da Abdib & Autoridade \\
\hline
\end{tabular}




\begin{tabular}{|c|c|c|c|c|c|}
\hline \multirow{2}{*}{\multicolumn{2}{|c|}{$26 / 6 / 2007 \mid \mathrm{DCI}$}} & \multirow{2}{*}{\multicolumn{2}{|c|}{$\begin{array}{l}\text { Governo aprova a retomada de Angra } \\
3\end{array}$}} & \multirow{2}{*}{\begin{tabular}{|l|} 
Marcos Costa, vice-presidente da Alstom \\
$\begin{array}{l}\text { Leonam dos Santos Guimarães, assistente da } \\
\text { Eletronuclear }\end{array}$
\end{tabular}} & \multirow{2}{*}{$\begin{array}{c}\text { Empresário } \\
\text { Autoridade }\end{array}$} \\
\hline & & & & & \\
\hline \multirow[t]{2}{*}{$26 / 06 / 07$} & Valor Econômico & $\begin{array}{l}\text { Conselho aprova construção de } \\
\text { Angra } 3\end{array}$ & Mista & $\begin{array}{l}\text { Nelson Hubner, ministro interino de Minas e } \\
\text { Energia }\end{array}$ & Autoridade \\
\hline & & & & $\begin{array}{l}\text { Guilherme Leonardi, coordenador do } \\
\text { Greenpeace }\end{array}$ & Protagonista \\
\hline \multirow[t]{2}{*}{$26 / 6 / 2007$} & A Tribuna & Governo retomará obras de Angra 3 & Mista & $\begin{array}{l}\text { Nelson Hubner, ministro interino de Minas e } \\
\text { Energia }\end{array}$ & Autoridade \\
\hline & & & & $\begin{array}{l}\text { Guilherme Leonardi, coordenador do } \\
\text { Greenpeace }\end{array}$ & Protagonista \\
\hline $26 / 6 / 2007$ & O Globo & Sinal verde para energia nuclear & Positiva & $\begin{array}{l}\text { Nelson Hubner, ministro interino de Minas e } \\
\text { Energia }\end{array}$ & Autoridade \\
\hline $27 / 6 / 2007$ & Folha de S. Paulo & $\begin{array}{l}\text { Marina quer isenção no } \\
\text { licenciamento para Angra } 3\end{array}$ & Mista & Marina Silva, ministra do Meio Ambiente & Autoridade \\
\hline
\end{tabular}




\begin{tabular}{|c|c|c|c|c|c|}
\hline & & & & $\begin{array}{l}\text { Othon Luiz Pinheiro, presidente da } \\
\text { Eletronuclear }\end{array}$ & Autoridade \\
\hline $27 / 6 / 2007$ & Folha de S. Paulo & $\begin{array}{l}\text { CNPE aprova construção de quatro } \\
\text { usinas }\end{array}$ & Positiva & Maurício Tolmasquim, presidente EPE & Autoridade \\
\hline $27 / 6 / 2007$ & Valor Econômico & $\begin{array}{l}\text { Eletronuclear cuidará dos rejeitos de } \\
\text { Angra } 3\end{array}$ & Positiva & Paulo Godoy, diretor da Abdib & Autoridade \\
\hline \multirow[t]{5}{*}{$27 / 6 / 2007$} & \multirow[t]{5}{*}{$\mathrm{DCI}$} & \multirow[t]{5}{*}{$\begin{array}{l}\text { Empresas iniciam batalha de bilhões } \\
\text { para atender Angra } 3\end{array}$} & \multirow[t]{5}{*}{ Positiva } & $\begin{array}{l}\text { Johannes Hoebart, presidente da divisão da } \\
\text { Areva nuclear no Brasil }\end{array}$ & Empresário \\
\hline & & & & Newton Duarte, diretor da Siemens & Empresário \\
\hline & & & & $\begin{array}{l}\text { Marcos Costa, vice-presidente regional da } \\
\text { Alstom }\end{array}$ & Empresário \\
\hline & & & & $\begin{array}{l}\text { Alfredo Tranjan Filho presidente, das Indústrias } \\
\text { Nucleares do Brasil }\end{array}$ & Autoridade \\
\hline & & & & $\begin{array}{l}\text { Leonam dos Santos, assessor da presidência da } \\
\text { Eletronuclear }\end{array}$ & Autoridade \\
\hline
\end{tabular}




\begin{tabular}{|c|c|c|c|c|c|}
\hline $27 / 6 / 2007$ & Jornal da Tarde & $\begin{array}{l}\text { Marina não confirma começo de } \\
\text { Angra } 3\end{array}$ & Mista & Marina Silva, ministra do Meio Ambiente & Autoridade \\
\hline \multirow[t]{4}{*}{$27 / 6 / 2007$} & \multirow[t]{4}{*}{ O Globo } & \multirow[t]{4}{*}{$\begin{array}{l}\text { Angra 3: obra em setembro, com } 9 \\
\text { mil empregos }\end{array}$} & \multirow[t]{4}{*}{ Positiva } & $\begin{array}{l}\text { Othon Luiz Pinheiro, presidente da } \\
\text { Eletronuclear }\end{array}$ & Autoridade \\
\hline & & & & Fernando Jordão, prefeito de Angra dos Reis & Autoridade \\
\hline & & & & $\begin{array}{l}\text { Manoel Francisco de Oliveira, presidente da } \\
\text { Turisangra }\end{array}$ & Usuário \\
\hline & & & & Alfredo Tranjan, presidente da INB & Autoridade \\
\hline $27 / 6 / 2007$ & O Globo & É preciso diversificar & Positiva & $\begin{array}{l}\text { Francisco Rondinelli, presidente da Aben } \\
\text { (Assoc. Brasileira de Energia Nuclear) }\end{array}$ & Autoridade \\
\hline $27 / 6 / 2007$ & O Globo & Vocação do Brasil é outra & Negativa & Luiz Pinguelli Rosa, físico Coppe UFRJ & Especialista \\
\hline $27 / 6 / 2007$ & O Estado de S. Paulo & Retomada de Angra 3 & Mista & $\begin{array}{l}\text { Nelson Hubner, ministro interino de Minas e } \\
\text { Energia }\end{array}$ & Autoridade \\
\hline
\end{tabular}




\begin{tabular}{|c|c|c|c|c|c|}
\hline $27 / 6 / 2007$ & O Globo & Energia polêmica & Negativa & Miriam Leitão & Protagonista \\
\hline $27 / 6 / 2007$ & O Globo & Decisão certa & Positiva & jornalista & Protagonista \\
\hline $27 / 6 / 2007$ & O Estado de S. Paulo & $\begin{array}{l}\text { Marina dá sinais de que Angra } 3 \\
\text { pode demorar }\end{array}$ & Negativa & Marina Silva, ministra do Meio Ambiente & Autoridade \\
\hline \multirow[t]{2}{*}{$27 / 6 / 2007$} & \multirow[t]{2}{*}{ O Estado de S. Paulo } & \multirow[t]{2}{*}{$\begin{array}{l}\text { Construção de usina não afasta risco } \\
\text { de apagão }\end{array}$} & \multirow[t]{2}{*}{ Mista } & Adriano Pires, diretor do CBIE & Protagonista \\
\hline & & & & $\begin{array}{l}\text { Claúdio Sales presidente do Instituto Acende } \\
\text { Brasil }\end{array}$ & Protagonista \\
\hline \multirow[t]{2}{*}{$27 / 6 / 2007$} & \multirow[t]{2}{*}{ O Estado de S. Paulo } & \multirow[t]{2}{*}{$\begin{array}{l}\text { Fatia da energia nuclear deve triplicar } \\
\text { até } 2030\end{array}$} & \multirow[t]{2}{*}{ Positiva } & Maurício Tolmasquim, presidente EPE & Autoridade \\
\hline & & & & $\begin{array}{l}\text { Luiz Fernando Pezão, governador em exercício } \\
\text { do RJ }\end{array}$ & Autoridade \\
\hline $28 / 6 / 2007$ & Gazeta Mercantil & $\begin{array}{l}\text { Energia nuclear não combate } \\
\text { aquecimento }\end{array}$ & Negativa & Jornalista & Protagonista \\
\hline \multirow[t]{2}{*}{$28 / 6 / 2007$} & \multirow[t]{2}{*}{ Folha de S. Paulo } & \multirow[t]{2}{*}{$\begin{array}{l}\text { Metade de Angra } 3 \text { não deve ter } \\
\text { licitação }\end{array}$} & \multirow[t]{2}{*}{ Mista } & $\begin{array}{l}\text { Othon Luiz Pinheiro da Silva, presidente da } \\
\text { Eletronuclear }\end{array}$ & Autoridade \\
\hline & & & & $\begin{array}{l}\text { Nelson Hubner, ministro interino de Minas e } \\
\text { Energia }\end{array}$ & Autoridade \\
\hline $28 / 6 / 2007$ & Folha de S. Paulo & $\begin{array}{l}\text { Financiamento virá de estatal, do } \\
\text { BNDES e de fora }\end{array}$ & Positiva & Eletronuclear & Autoridade \\
\hline
\end{tabular}




\begin{tabular}{|c|c|c|c|c|c|}
\hline $28 / 6 / 2007$ & Folha de S. Paulo & $\begin{array}{l}\text { Em } 21 \text { anos, fornecedores foram } \\
\text { vendidos ou fecharam as portas }\end{array}$ & Mista & Carlos Ari Sundfeld, especialista em direito & Especialista \\
\hline $28 / 6 / 2007$ & Folha de S. Paulo & $\begin{array}{l}\text { Mundo não pode arcar com solução } \\
\text { nuclear para crise do clima, diz } \\
\text { estudo }\end{array}$ & Negativa & Oxford Research Group & Especialista \\
\hline $28 / 6 / 2007$ & O Estado de S. Paulo & SP tem ato contra usina nuclear & Negativa & Roberto Franco, da Econg & Protagonista \\
\hline \multirow[t]{3}{*}{$29 / 6 / 2007$} & \multirow[t]{3}{*}{7 O Estado de S. Paulo } & \multirow[t]{3}{*}{ E lá vamos nós de energia nuclear } & \multirow[t]{3}{*}{ Negativa } & Marina Silva, ministra do meio ambiente & Autoridade \\
\hline & & & & $\begin{array}{l}\text { Joaquim Francisco de Carvalho, diretor } \\
\text { industrial da Nuclen }\end{array}$ & Autoridade \\
\hline & & & & José Goldemberg, físico & Especialista \\
\hline $29 / 6 / 2007$ & Gazeta Mercantil & $\begin{array}{l}\text { Governo de SP rejeita usina nuclear } \\
\text { no estado }\end{array}$ & Negativa & $\begin{array}{l}\text { Dilma Celi Pena, secretária estadual de } \\
\text { Saneamento e Energia }\end{array}$ & Autoridade \\
\hline $29 / 6 / 2007$ & Gazeta Mercantil & $\begin{array}{l}\text { Governo de SP rejeita usina nuclear } \\
\text { no estado }\end{array}$ & Negativa & $\begin{array}{l}\text { Dilma Celi Pena, secretária estadual de } \\
\text { Saneamento e Energia }\end{array}$ & Autoridade \\
\hline $29 / 6 / 2007$ & $\mathrm{DCI}$ & $\begin{array}{l}\text { Energia nuclear ganha espaço no } \\
\text { mundo, com } 286 \text { novos reatores }\end{array}$ & Positiva & Instituto de Engenharia & Especialista \\
\hline
\end{tabular}




\begin{tabular}{|c|c|c|c|c|c|}
\hline \multirow{3}{*}{\multicolumn{2}{|c|}{ 29/6/2007|Gazeta Mercantil }} & \multirow[t]{3}{*}{ Angra 3 a um passo da realidade } & \multirow[t]{3}{*}{ Positiva } & $\begin{array}{l}\text { Leonam dos Santos Guimarães, assessor do } \\
\text { presidente da Eletronuclear }\end{array}$ & Autoridade \\
\hline & & & & $\begin{array}{l}\text { Nelson Hubner, ministro interino de Minas e } \\
\text { Energia }\end{array}$ & Autoridade \\
\hline & & & & Alfredo Tranjan Filho, presidente da INB & Autoridade \\
\hline $29 / 6 / 2007$ & $\mathrm{DCI}$ & $\begin{array}{l}\text { Desperdício de energia no País } \\
\text { equivale a cinco usinas Angra } 3\end{array}$ & Positiva & Maurício Tolmasquim, presidente da EPE & Autoridade \\
\hline \multirow[t]{2}{*}{$29 / 6 / 2007$} & \multirow[t]{2}{*}{ Valor Econômico } & \multirow[t]{2}{*}{$\begin{array}{l}\text { Angra } 3 \text { poderá ter nova licitação de } \\
\text { equipamentos }\end{array}$} & \multirow[t]{2}{*}{ Positiva } & $\begin{array}{l}\text { Leonam dos Santos Guimarães, assessor do } \\
\text { presidente da Eletronuclear }\end{array}$ & Autoridade \\
\hline & & & & Antonio Muller, presidente da Abdan & Autoridade \\
\hline $29 / 6 / 2007$ & Folha de S. Paulo & $\begin{array}{l}\text { País deve explorar nova mina de } \\
\text { urânio }\end{array}$ & Positiva & Alfredo Tranjan, presidente da INB & Autoridade \\
\hline
\end{tabular}




\begin{tabular}{|c|c|c|c|c|c|}
\hline & & & & $\begin{array}{l}\text { Samuel Fayad Filho, diretor de combustível } \\
\text { nuclear da INB }\end{array}$ & Autoridade \\
\hline $29 / 6 / 2007$ & DCI & $\begin{array}{l}\text { Brasil pode exportar urânio, que } \\
\text { movimenta US\$ } 20 \text { bi }\end{array}$ & Positiva & $\begin{array}{l}\text { Samuel Fayad Filho, diretor de combustível } \\
\text { nuclear da INB }\end{array}$ & Autoridade \\
\hline \multirow[t]{2}{*}{$30 / 6 / 2007$} & \multirow[t]{2}{*}{ O Globo } & \multirow[t]{2}{*}{ Ambição Nuclear } & \multirow[t]{2}{*}{ Mista } & Marina Silva, ministra do Meio Ambiente & Autoridade \\
\hline & & & & $\begin{array}{l}\text { Sérgio Rezende, ministro de Ciência e } \\
\text { Tecnologia }\end{array}$ & Autoridade \\
\hline $30 / 6 / 2007$ & Folha de S. Paulo & $\begin{array}{l}\text { Em plano, governo já prevê atraso } \\
\text { em Angra } 3\end{array}$ & Negativa & Ministério de Minas e Energia & Autoridade \\
\hline $1 / 7 / 2007$ & O Estado de S. Paulo & $\begin{array}{l}\text { Programa nuclear pode custar } \mathrm{R} \$ 55 \\
\text { bi }\end{array}$ & Mista & Gorete Paulo FGV-RJ, Paulo Godoy Abdib & Especialista \\
\hline \multirow[t]{3}{*}{$1 / 7 / 2007$} & \multirow[t]{3}{*}{ O Estado de S. Paulo } & \multirow[t]{3}{*}{$\begin{array}{l}\text { Angra } 3 \text { marca fim do ciclo de } \\
\text { energia barata }\end{array}$} & \multirow[t]{3}{*}{ Negativa } & Maurício Tolmasquim, presidente da EPE & Autoridade \\
\hline & & & & José Goldemberg, físico & Especialista \\
\hline & & & & Gorete Paulo, FGV-RJ & Especialista \\
\hline
\end{tabular}




\begin{tabular}{|c|c|c|c|c|c|}
\hline \multicolumn{2}{|c|}{ 02/07/07|Época } & \multirow[t]{4}{*}{ Quem paga a conta de Angra 3? } & Negativa & José Goldemberg, físico & Especialista \\
\hline & & & & Claúdio Sales, do Instituto Acende Brasil & Protagonista \\
\hline & & & & Marina Silva, ministra do Meio Ambiente & Autoridade \\
\hline & & & & Luiz Pinguelli Rosa, da Coppe -UFRJ & Especialista \\
\hline $2 / 7 / 2007$ & A Tribuna & Angra 3, uma opção válida & Positiva & Jornalista & Protagonista \\
\hline $2 / 7 / 2007$ & Folha de S. Paulo & $\begin{array}{l}\text { Desde a década de } 70 \text {, só } 22 \% \text { do } \\
\text { programa nuclear saiu do papel }\end{array}$ & Negativa & $\begin{array}{l}\text { Pedro Figueiredo, diretor de Operações da } \\
\text { central }\end{array}$ & Usuário \\
\hline \multirow[t]{3}{*}{$2 / 7 / 2007$} & \multirow[t]{3}{*}{ Folha de S. Paulo } & \multirow[t]{3}{*}{$\begin{array}{l}\text { Município quer contrapartidas para } \\
\text { compensar impacto ambiental e } \\
\text { social }\end{array}$} & \multirow[t]{3}{*}{ Negativa } & Fernando Jordão, prefeito de Angra dos Reis & Usuário \\
\hline & & & & $\begin{array}{l}\text { Claudemiro Raimundo Cipriano, pescador de } \\
\text { Angra }\end{array}$ & Usuário \\
\hline & & & & Odir Duarte, vereador & Autoridade \\
\hline \multirow[t]{2}{*}{$2 / 7 / 2007$} & \multirow[t]{2}{*}{ O Estado de S. Paulo } & \multirow[t]{2}{*}{$\begin{array}{l}\text { Ambientalistas diminuem resistência } \\
\text { à energia nuclear }\end{array}$} & \multirow[t]{2}{*}{ Mista } & James Lovelock, cientista inglês & Especialista \\
\hline & & & & Patrick Moore, fundador do Greenpeace & Protagonista \\
\hline
\end{tabular}




\begin{tabular}{|c|c|c|c|c|c|}
\hline & & & & Fernando Almeida, presidente do CEBDS & Protagonista \\
\hline & & & & $\begin{array}{l}\text { Ana Cristina Barros, da ONG Nature } \\
\text { Conservancy }\end{array}$ & Protagonista \\
\hline & & & & $\begin{array}{l}\text { Guilherme } \\
\text { Leonardi, do Greenpeace }\end{array}$ & Protagonista \\
\hline $2 / 7 / 2007$ & O Estado de S. Paulo & Novas Angras serão $71 \%$ nacionais & Positiva & $\begin{array}{l}\text { Especialista } \\
\text { consultado pelo jornal }\end{array}$ & Especialista \\
\hline $2 / 7 / 2007$ & Jornal do Brasil & Energia nuclear aquece economia & Positiva & Jornalista & Protagonista \\
\hline $2 / 7 / 2007$ & Jornal do Brasil & Falta mão-de-obra & Negativa & Jornalista & Protagonista \\
\hline $2 / 7 / 2007$ & Jornal do Brasil & Corrida ao urânio & Positiva & Jornalista & Protagonista \\
\hline $2 / 7 / 2007$ & Jornal do Brasil & Angra quer contrapartida ambiental & Negativa & Fernando Jordão, prefeito de Angra dos Reis & Autoridade \\
\hline $3 / 7 / 2007$ & Folha de S. Paulo & $\begin{array}{l}\text { Governo pretende criar estatal para } \\
\text { cuidar dos rejeitos nucleares }\end{array}$ & Positiva & Leonam dos Santos Guimarães & Autoridade \\
\hline $4 / 7 / 2007$ & Valor Econômico & $\begin{array}{l}\text { Passividade marca a atitude dos } \\
\text { verdes diante de Angra } 3\end{array}$ & Mista & $\begin{array}{l}\text { Carlos Minc, secretário do meio ambiente do } \\
\text { RJ }\end{array}$ & Autoridade \\
\hline
\end{tabular}




\begin{tabular}{|c|c|c|c|c|c|}
\hline \multirow{2}{*}{\multicolumn{2}{|c|}{ 4/7/2007/Valor Econômico }} & \multirow[t]{2}{*}{$\begin{array}{l}\text { Verdes estão paralisados diante de } \\
\text { Angra } 3\end{array}$} & \multirow[t]{2}{*}{ Mista } & $\begin{array}{l}\text { Frank Guggenheim, diretor executivo do } \\
\text { Greenpeace }\end{array}$ & Protagonista \\
\hline & & & & $\begin{array}{l}\text { Carlos Minc, secretário do Meio Ambiente do } \\
\text { RJ }\end{array}$ & Autoridade \\
\hline $4 / 7 / 2007$ & $7 \longdiv { O }$ Estado de S. Paulo & Angra 3 e a racionalidade econômica & Mista & Cláudio Sales, presidente do Acende Brasil & Protagonista \\
\hline $4 / 7 / 2007$ & 7Isto É & A opção nuclear & Mista & Carlos José Marques, jornalista & Protagonista \\
\hline $4 / 7 / 2007$ & 7 Isto É & O Plano nuclear de Lula & Mista & $\begin{array}{l}\text { Sérgio Rezende, ministro de Ciência e } \\
\text { Tecnologia }\end{array}$ & Autoridade \\
\hline & & & & Marina Silva, ministra do Meio Ambiente & Autoridade \\
\hline & & & & $\begin{array}{l}\text { Guilherme } \\
\text { Leonardi, coordenador do Greenpeace }\end{array}$ & Protagonista \\
\hline & & & & Francisco Rondinelli, presidente da Aben & Autoridade \\
\hline $5 / 7 / 2007$ & 7 Jornal do Brasil & Enfim, Angra 3 & Positiva & Wagner Granja, Victor pres. do Cedae & Autoridade \\
\hline
\end{tabular}









\begin{tabular}{|c|c|c|c|c|c|}
\hline \multirow{2}{*}{\multicolumn{2}{|c|}{ 11/7/2007|A Cidade }} & \multirow[t]{2}{*}{ Região poderá ter usina nuclear } & \multirow[t]{2}{*}{ Positiva } & \multirow{2}{*}{\begin{tabular}{|l|} 
Othon Pinheiro da Silva, Eletronuclear \\
Ricardo Lima, secretario de Meio Ambiente
\end{tabular}} & \multirow{2}{*}{$\begin{array}{l}\text { Autoridade } \\
\text { Autoridade }\end{array}$} \\
\hline & & & & & \\
\hline $12 / 7 / 2007$ & Folha de S. Paulo & Emersão nuclear & Positiva & $\begin{array}{l}\text { Sérgio Rezende, ministro de Ciência e } \\
\text { Tecnologia }\end{array}$ & Autoridade \\
\hline \multirow[t]{2}{*}{$12 / 7 / 2007$} & O Diário & Região pode ter usinas nucleares & Positiva & $\begin{array}{l}\text { Sérgio Rezende, ministro de Ciência e } \\
\text { Tecnologia }\end{array}$ & Autoridade \\
\hline & & & & Francisco Rondinelli & Autoridade \\
\hline $13 / 7 / 2007$ & O Globo & 30 anos depois & Mista & Merval Pereira & Protagonista \\
\hline $14 / 7 / 2007$ & Folha de S. Paulo & $\begin{array}{l}\text { A energia nuclear é uma boa solução } \\
\text { para o Brasil }\end{array}$ & Mista & Odair Dias Gonçalves, pres. da CNEN & Autoridade \\
\hline $16 / 7 / 2007$ & Exame & A nuclear adere à energia eólica & Mista & Jornalista & Protagonista \\
\hline \multirow[t]{2}{*}{$7 / 8 / 2007$} & \multirow[t]{2}{*}{ Gazeta Mercantil } & \multirow[t]{2}{*}{$\begin{array}{l}\text { Obras de Angra três devem } \\
\text { recomeçar este ano }\end{array}$} & \multirow[t]{2}{*}{ Positiva } & $\begin{array}{l}\text { Sérgio Rezende, ministro de Ciência e } \\
\text { Tecnologia }\end{array}$ & Autoridade \\
\hline & & & & Luiz Pinguelli Rosa Coppe/ RJ & Especialista \\
\hline $7 / 8 / 2007$ & $7 \longdiv { O }$ Estado de S. Paulo & $\begin{array}{l}\text { Lula promete fazer do País um } \\
\text { canteiro de obras }\end{array}$ & Positiva & Luiz Inácio Lula da Silva, pres. da República & Autoridade \\
\hline $8 / 8 / 2007$ & $7 \mathrm{DCI}$ & $\begin{array}{l}\text { Usina Nuclear de } 1.000 \text { megawatts } \\
\text { terá local definido ainda este ano }\end{array}$ & Positiva & Maurício Tolmasquim, EPE & Autoridade \\
\hline
\end{tabular}




\begin{tabular}{|c|c|c|c|c|c|}
\hline & & & & Silvia Calou, diretora $\mathrm{ABCE}$ & Protagonista \\
\hline \multirow[t]{2}{*}{$8 / 8 / 2007$} & \multirow[t]{2}{*}{$7 \mathrm{DCI}$} & \multirow[t]{2}{*}{$\begin{array}{l}\text { Toshiba mira vender equipamento à } \\
\text { usina }\end{array}$} & \multirow[t]{2}{*}{ Positiva } & Atsutoshi Nishida, pres. Toshiba & Empresário \\
\hline & & & & Murício Tolamsquim, pres. EPE & Autoridade \\
\hline \multirow[t]{2}{*}{$10 / 8 / 2007$} & \multirow[t]{2}{*}{ O Globo } & \multirow[t]{2}{*}{$\begin{array}{l}\text { Um programa estatal só para uma } \\
\text { usina }\end{array}$} & \multirow[t]{2}{*}{ Mista } & Othon Pinheiro da Silva, pres. Eletronuclear & Autoridade \\
\hline & & & & Maurício Grinberg, INB & Autoridade \\
\hline $12 / 8 / 2007$ & O Globo & Rebeldes & Negativa & Jornalista & Protagonista \\
\hline $13 / 8 / 2007$ & Mogi News & Factóides & Negativa & Jornalista & Protagonista \\
\hline \multirow[t]{2}{*}{$16 / 8 / 2007$} & \multirow[t]{2}{*}{ Valor Econômico } & \multirow[t]{2}{*}{$\begin{array}{l}\text { Energia elétrica: diversificar as fontes } \\
\text { para não faltar }\end{array}$} & \multirow[t]{2}{*}{ Positiva } & $\begin{array}{l}\text { Sérgio Rezende, ministro de Ciência e } \\
\text { Tecnologia }\end{array}$ & Autoridade \\
\hline & & & & Nelson Hubner, ministro de Minas e Energia & Autoridade \\
\hline $22 / 8 / 2007$ & Gazeta Mercantil & $\begin{array}{l}\text { O Brasil diante de mudanças } \\
\text { climáticas }\end{array}$ & Positiva & Edson Kuramoto, diretor de comunicação Aben & Autoridade \\
\hline $28 / 8 / 2007$ & Folha de S. Paulo & $\begin{array}{l}\text { Procuradoria pede ação contra Angra } \\
3\end{array}$ & Negativa & Jornalista & Protagonista \\
\hline
\end{tabular}




\begin{tabular}{|c|c|c|c|c|c|}
\hline \multirow{5}{*}{\multicolumn{2}{|c|}{ 29/8/2007|DCI }} & \multirow[t]{5}{*}{$\begin{array}{l}\text { Preço do gás em alta dá novo } \\
\text { impulso à energia nuclear }\end{array}$} & \multirow[t]{5}{*}{ Mista } & Aquilino Senra, vice diretor Coppe/UFRJ & Especialista \\
\hline & & & & Maurício Tolmasquim, pres. EPE & Autoridade \\
\hline & & & & $\begin{array}{l}\text { Ronaldo Fabrício, ex pres. de Furnas e } \\
\text { Eletronuclear }\end{array}$ & Autoridade \\
\hline & & & & Alfredo Tranjan Filho pres. INB & Autoridade \\
\hline & & & & $\begin{array}{l}\text { José Goldemberg, ex-secretário do Meio } \\
\text { Ambiente SP }\end{array}$ & Especialista \\
\hline $28 / 8 / 2007$ & O Estado de S. Paulo & $\begin{array}{l}\text { MP quer suspender audiência de } \\
\text { Angra } 3\end{array}$ & Negativa & $\begin{array}{l}\text { Roberto Messias Franco, dir. Licenciamento } \\
\text { Ambiental do Ibama }\end{array}$ & Autoridade \\
\hline \multirow[t]{2}{*}{$28 / 8 / 2007$} & \multirow[t]{2}{*}{ Valor Econômico } & \multirow[t]{2}{*}{$\begin{array}{l}\text { MP quer suspender o processo de } \\
\text { licenciamento ambiental de Angra } 3\end{array}$} & \multirow[t]{2}{*}{ Mista } & André de Vasconcelos, proc. da República & Autoridade \\
\hline & & & & $\begin{array}{l}\text { Leonam dos Santos Guimarães, da } \\
\text { Eletronuclear }\end{array}$ & Autoridade \\
\hline
\end{tabular}




\begin{tabular}{|c|c|c|c|c|c|}
\hline & & & & Roberto Messias, do Ibama & Especialista \\
\hline \multirow[t]{2}{*}{$13 / 9 / 2007$} & \multirow[t]{2}{*}{ Valor Econômico } & \multirow{2}{*}{$\begin{array}{l}\text { Renascimento nuclear já dá as caras } \\
\text { nos EUA }\end{array}$} & \multirow[t]{2}{*}{ Mista } & Dale Klein, pres. da NRC & Autoridade \\
\hline & & & & Harry Reid, senador de Nevada & Autoridade \\
\hline $18 / 9 / 2007$ & O Globo & $\begin{array}{l}\text { Reator de Chernobyl será coberto por } \\
\text { gigantesca "caixa" de aço }\end{array}$ & Negativa & jornalista & Protagonista \\
\hline \multirow[t]{2}{*}{$25 / 9 / 2007$} & \multirow[t]{2}{*}{ Folha de S. Paulo } & \multirow[t]{2}{*}{$\begin{array}{l}\text { MPF acusa órgão que fiscaliza } \\
\text { energia nuclear }\end{array}$} & \multirow[t]{2}{*}{ Mista } & André Vasconcelos, proc. da República & Autoridade \\
\hline & & & & Odair Gonçalves, pres. Cnen & Autoridade \\
\hline 28/9/2007 & O Estado de S. Paulo & Do césio 137 à usina nuclear Angra 3 & Negativa & Washington Novaes, jornalista & Protagonista \\
\hline \multirow[t]{3}{*}{$2 / 10 / 2007$} & \multirow[t]{3}{*}{ Correio Popular } & \multirow[t]{3}{*}{ Resíduo radioativo continua em Itu } & \multirow[t]{3}{*}{ Mista } & Herculano Passos Junior, prefeito de Itu & Autoridade \\
\hline & & & & Luiz Carlos Mazzini, Depart. Meio Ambiente & Especialista \\
\hline & & & & Roberval Tonon, físico & Especialista \\
\hline $21 / 10 / 2007$ & Folha de S. Paulo & $\begin{array}{l}\text { Depender de combustível natural traz } \\
\text { risco, vê físico }\end{array}$ & Mista & Jonathan Tennenbaum, físico americano & Especialista \\
\hline $25 / 10 / 2007$ & Gazeta Mercantil & $\begin{array}{l}\text { Usina nuclear vira arma contra } \\
\text { emissões de } \mathrm{CO} 2\end{array}$ & Negativa & Jornalista & Protagonista \\
\hline
\end{tabular}




\begin{tabular}{|c|c|c|c|c|c|}
\hline $7 / 11 / 2007$ & O Globo & $\begin{array}{l}\text { Vale investirá em geração de energia } \\
\text { própria }\end{array}$ & Positiva & Roger Agnelli, pres. da Vale & Empresário \\
\hline \multirow[t]{2}{*}{$7 / 11 / 2007$} & \multirow[t]{2}{*}{ Gazeta Mercantil } & \multirow[t]{2}{*}{ CVRD quer construir usina nuclear } & \multirow[t]{2}{*}{ Positiva } & Roger Agnelli, pres. da Vale & Empresário \\
\hline & & & & $\begin{array}{l}\text { Tito Martins, diretor executivo do setor de } \\
\text { energia }\end{array}$ & Autoridade \\
\hline $8 / 11 / 2007$ & O Globo & $\begin{array}{l}\text { Para consultor, biomassa em vez de } \\
\text { nuclear }\end{array}$ & Negativa & David Zylbersztajn, presidiu a ANP & Autoridade \\
\hline $26 / 11 / 2007$ & Folha de S. Paulo & $\begin{array}{l}\text { Plano energético prevê construção de } \\
\text { até } 8 \text { usinas nucleares no país }\end{array}$ & Positiva & Givaldo Lessa Castro, geólogo & Especialista \\
\hline \multirow[t]{2}{*}{$27 / 11 / 2007$} & \multirow[t]{2}{*}{ A Tribuna } & \multirow[t]{2}{*}{$\begin{array}{l}\text { Aberta audiência pública sobre Angra } \\
3\end{array}$} & \multirow[t]{2}{*}{ Negativa } & Ariane de Alencar, proc. da República, & Autoridade \\
\hline & & & & Antônio Cordeiro, líder do PT. & Autoridade \\
\hline $27 / 11 / 2007$ & Valor Econômico & $\begin{array}{l}\text { ONG projeta nível de CO2 a ser } \\
\text { emitido por Angra } 3\end{array}$ & Negativa & Rebeca Lerner, do Greenpeace & Protagonista \\
\hline $27 / 11 / 2007$ & Gazeta Mercantil & $\begin{array}{l}\text { Usina contribui para o efeito estufa, } \\
\text { diz Greenpeace }\end{array}$ & Negativa & Rebeca Lerner, do Greenpeace & Protagonista \\
\hline \multirow[t]{2}{*}{$27 / 11 / 2007$} & \multirow[t]{2}{*}{ O Estado de S. Paulo } & \multirow[t]{2}{*}{ Angra 3 é discutida sob protestos } & \multirow[t]{2}{*}{ Negativa } & Ariane de Alencar, proc. República & Autoridade \\
\hline & & & & Antônio Cordeiro, líder do PT & Autoridade \\
\hline
\end{tabular}




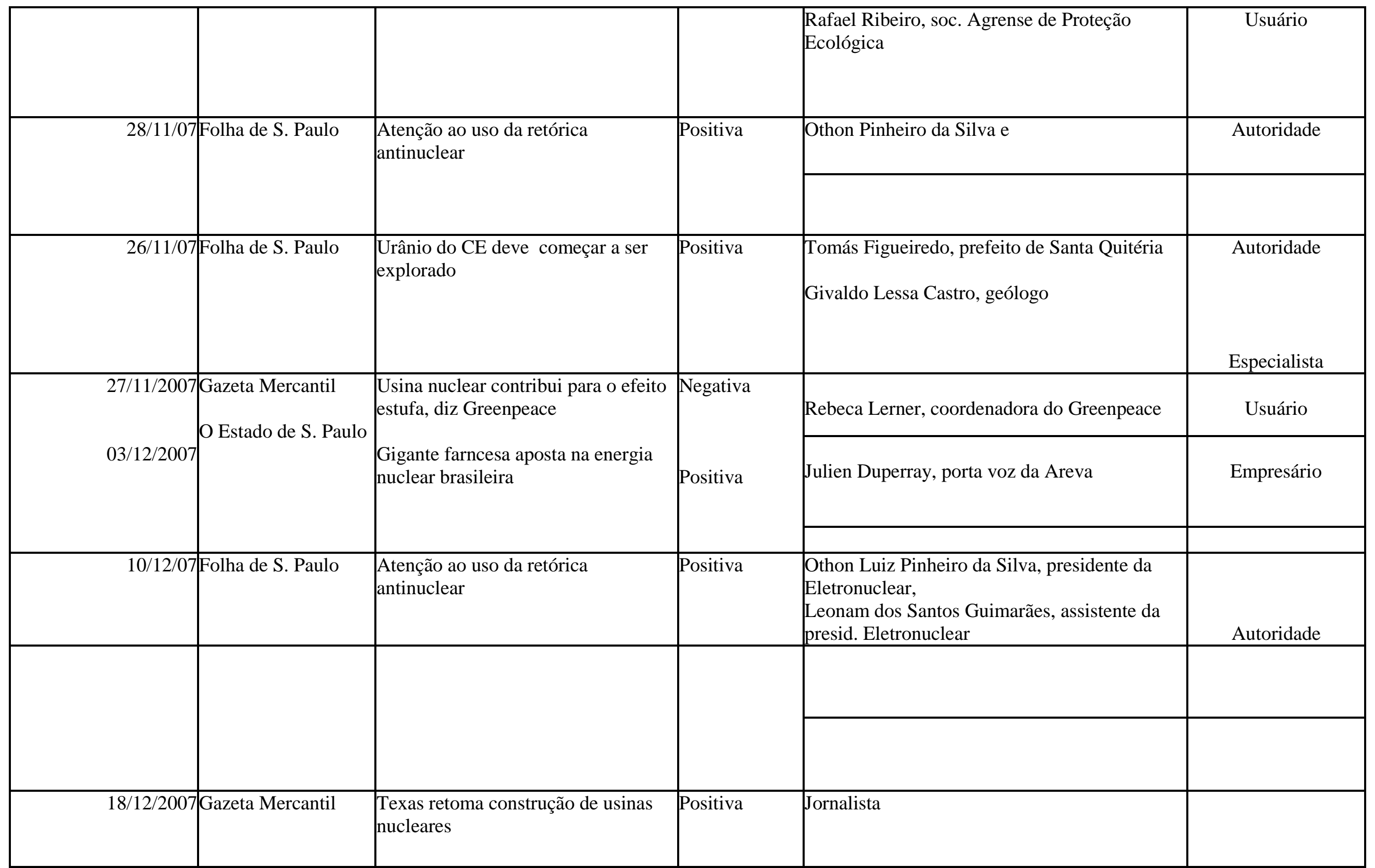




\begin{tabular}{|c|c|c|c|c|c|}
\hline & & & & Nelson Jobim, ministro da Defesa & Autoridade \\
\hline & & & & Othon Pinheiro da Silva, da Eletronuclear & Autoridade \\
\hline $22 / 12 / 2007$ & O Estado de S. Paulo & $\begin{array}{l}\text { Eletronuclear quer concluir Angra } 3 \\
\text { em } 2014\end{array}$ & Positiva & Nelson Jobim, ministro da Defesa & Autoridade \\
\hline $22 / 12 / 07$ & Jornal do Brasil & $\begin{array}{l}\text { Construção de Angra } 3 \text { vai começar } \\
\text { em setembro }\end{array}$ & Positiva & Othon Pinheiro da Silva, da Eletronuclear & Autoridade \\
\hline $17 / 1 / 2008$ & $\mathrm{DCI}$ & $\begin{array}{l}\text { Justiça carioca paralisa processo de } \\
\text { licenciamento da usina Angra } 3\end{array}$ & Negativa & $\begin{array}{l}\text { Leonam dos Santos Guimarães, da } \\
\text { Eletronuclear }\end{array}$ & Autoridade \\
\hline $17 / 1 / 2008$ & O Estado de S. Paulo & Novos perigos das armas nucleares & Negativa & Celso Lafer, professor de Direito da USP & \\
\hline
\end{tabular}

Fonte: o próprio autor 


\subsection{Frequência das fontes de informação}

A Tabela 7 apresenta o número de matérias e discursos analisados por fonte de informação, em cada veículo de comunicação.

Tabela 7 - Número de matérias e discursos analisados por veículo de comunicação

\begin{tabular}{|c|c|c|c|c|c|c|c|}
\hline \multirow[t]{2}{*}{$\begin{array}{c}\text { Veículo de } \\
\text { comunicação }\end{array}$} & \multirow{2}{*}{$\begin{array}{l}\text { Número } \\
\text { de } \\
\text { matérias }\end{array}$} & \multicolumn{6}{|c|}{ Número de discursos } \\
\hline & & PR & AU & US & $\mathrm{ES}$ & EM & Total \\
\hline A Cidade & 1 & - & 2 & - & - & - & 2 \\
\hline Agora São Paulo & 1 & - & 1 & - & - & - & 1 \\
\hline A Tribuna & 4 & 2 & 3 & - & 1 & - & 6 \\
\hline Correio Brasiliense & 1 & - & - & - & 1 & - & 1 \\
\hline Correio Popular & 1 & - & 1 & - & 2 & - & 3 \\
\hline Diário do $\mathrm{ABC}$ & 3 & 1 & 1 & - & 1 & - & 3 \\
\hline Diário de São Paulo & 2 & - & 1 & - & 1 & - & 2 \\
\hline DCI & 14 & 2 & 15 & 1 & 5 & 5 & 28 \\
\hline Época & 1 & 1 & 1 & - & 2 & - & 4 \\
\hline Exame & 1 & 1 & - & - & - & - & 1 \\
\hline Folha de S. Paulo & 34 & 4 & 34 & 3 & 7 & 1 & 49 \\
\hline Gazeta Mercantil & 15 & 5 & 12 & 1 & 3 & 2 & 23 \\
\hline Isto É & 2 & 2 & 3 & - & - & - & 5 \\
\hline Jornal do Brasil & 8 & 4 & 4 & - & - & - & 8 \\
\hline Jornal da Tarde & 1 & - & 1 & - & - & - & 1 \\
\hline Mogi News & 1 & 1 & - & - & - & - & 1 \\
\hline O Diário & 1 & - & 2 & - & - & - & 2 \\
\hline O Empreiteiro & 1 & 1 & - & - & - & - & 1 \\
\hline O Estado de SP & 47 & 14 & 37 & 1 & 12 & 1 & 65 \\
\hline O Globo & 16 & 5 & 13 & 1 & 1 & 1 & 21 \\
\hline Valor Econômico & 15 & 4 & 17 & 3 & 2 & 1 & 27 \\
\hline Veja & 1 & - & - & - & 1 & - & 1 \\
\hline Total & 172 & 47 & 148 & 10 & 39 & 11 & 255 \\
\hline
\end{tabular}

PR: Protagonista; AU: Autoridade; US: Usuário; ES: Especialista; EM: Empresário

Verifica-se que as reportagens analisadas concentraram-se em grande parte nos jornais de maior circulação no Estado de São Paulo, com O Estado de São Paulo e Folha de São Paulo respondendo por $47,1 \%$ do total das matérias consideradas neste estudo. Constatou-se, portanto, cobertura jornalística maior sobre o tema em jornais de grande circulação, ocorrendo uma diminuição da cobertura à medida que se reduz o porte do veículo.

De um total de 255 discursos analisados, distribuídos nas 172 reportagens dos 22 veículos de comunicação, nota-se que houve predominância da fonte "autoridade" $(58,0 \%)$, seguida de protagonistas $(18,5 \%)$, especialistas $(15,3 \%)$, empresários $(4,3 \%)$ e usuários $(3,9 \%)$. 
A categoria 'autoridade' destacou-se por ser a fonte predominante nas matérias, ocorrendo na maioria dos veículos de mídia impressa; isso está relacionado, provavelmente, à responsabilidade da categoria em projetar soluções e propor alternativas para a possível escassez da energia advinda dos combustíveis fósseis.

No jornalismo científico, no entanto, o uso acentuado da fonte 'autoridade' é visto com cautela, uma vez que se essa fonte for oficial, ou seja, a ela pertencer o domínio da informação ou ser a geradora da informação, o jornalista encontrará dificuldades para checar os dados por ela transmitidos.

Como o estudo recorre à análise do discurso que aponta a fonte como 'dona de um dado discurso', observa-se certo amadurecimento na cobertura da imprensa por priorizar as fontes oficiais, no caso as autoridades e os especialistas.

No caso da fonte 'especialista', outro cuidado também deve ser tomado, isso porque o jornalista foi treinado, desde o início da sua formação, a ver o cientista, o especialista, como uma fonte inquestionável, o que tende a comprometer o debate previsto pelo jornalismo.

\subsection{Análise da Abordagem}

O discurso das fontes de informação foi classificado de acordo com a abordagem apresentada, positiva ou negativa, se favorável ou não à energia nuclear. Classificou-se como abordagem mista quando não foi possível identificar claramente o posicionamento da fonte, ou quando, em uma mesma matéria, duas ou mais fontes apresentaram posições antagônicas entre si.

A Tabela 8 apresenta a freqüência de ocorrência de cada abordagem, para cada veículo de comunicação. Observa-se que em 49,4\% das matérias analisadas a energia nuclear é abordada de uma forma positiva, contra 25,6\% da abordagem negativa e 25,0\% da abordagem mista. 
Tabela 8 - Número de tipos de abordagem por veiculo de comunicação

\begin{tabular}{|l|c|c|c|c|}
\hline \multirow{2}{*}{ Veículo } & \multicolumn{4}{|c|}{ Tipo de Abordagem } \\
\cline { 2 - 5 } & Positiva & Negativa & Mista & Total \\
\hline A Cidade & 1 & - & - & 1 \\
\hline Agora S. Paulo & 1 & - & - & 1 \\
\hline A Tribuna & 1 & 2 & 1 & 4 \\
\hline Correio Brasiliense & - & 1 & - & 1 \\
\hline Correio Popular & - & - & 1 & 1 \\
\hline Diário do ABC & 2 & - & 1 & 3 \\
\hline Diário de S. Paulo & 2 & - & - & 2 \\
\hline DCI & 10 & 2 & 3 & 15 \\
\hline Época & - & 1 & - & 1 \\
\hline Exame & - & - & 1 & 1 \\
\hline Folha de S. Paulo & 16 & 7 & 11 & 34 \\
\hline Gazeta Mercantil & 8 & 7 & - & 15 \\
\hline Isto É & - & - & 2 & 2 \\
\hline Jornal do Brasil & 6 & 2 & - & 8 \\
\hline Jornal da Tarde & - & - & 1 & 1 \\
\hline Mogi News & - & 1 & - & 1 \\
\hline O Diário & - & 1 & - & 1 \\
\hline O Empreiteiro & - & - & 1 & 1 \\
\hline O Estado de SP & 24 & 12 & 11 & 47 \\
\hline O Globo & 7 & 5 & 4 & 16 \\
\hline Valor Econômico & 6 & 3 & 6 & 15 \\
\hline Veja & 1 & - & - & 1 \\
\hline Total & 85 & 44 & 43 & 172 \\
\hline
\end{tabular}

O gráfico 3 apresenta a distribuição temporal das notícias ao longo do período estudado, destacando o tipo de abordagem veiculada. Percebe-se que os picos de matéria foram observadas nos meses de junho e julho, logo após a divulgação do $4^{\circ}$ Relatório do IPCC, quando o aquecimento global e fontes alternativas de energia foram assuntos freqüentes na mídia.

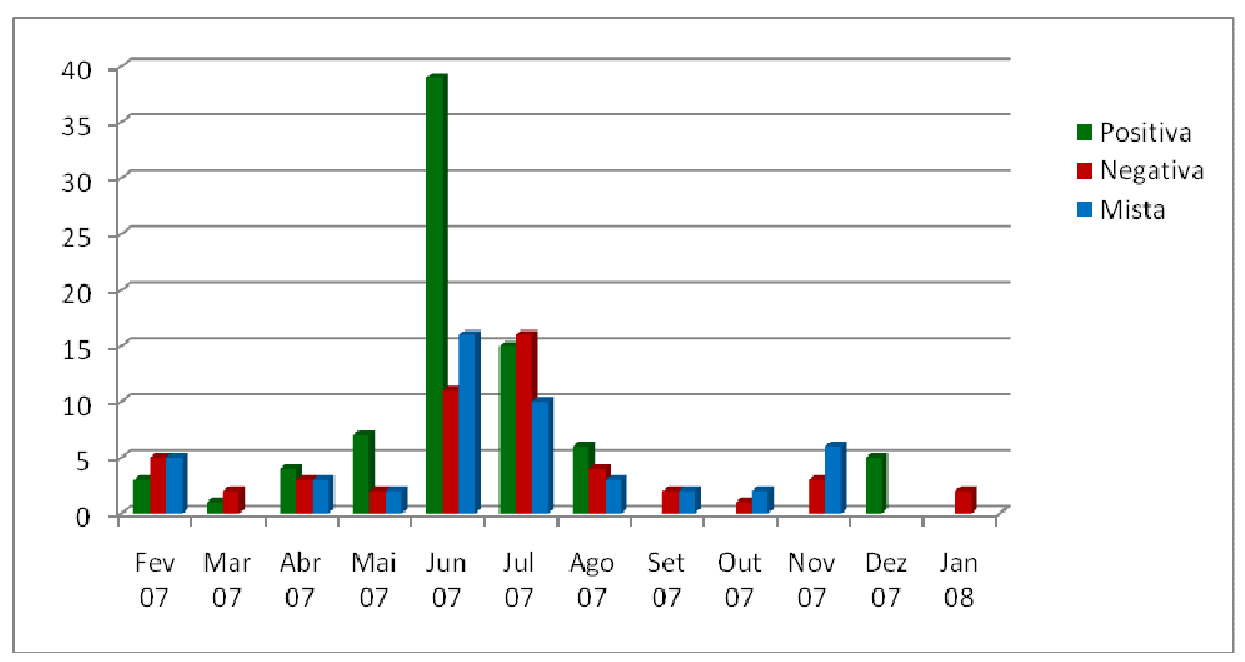

Gráfico 3 - Distribuição temporal das notícias ao longo do período estudado 
Do total de $75 \%$ das matérias com abordagem positiva ou negativa, a Tabela 9 apresenta a frequiência dessas ocorrências em função do tipo de fonte que efetuou o discurso. Observa-se uma clara tendência por parte de autoridades e empresários em transmitir uma imagem positiva da energia nuclear, em contraposição à imagem negativa apresentada por protagonistas.

Tabela 9 - Número de tipos de abordagem por fonte de informação

\begin{tabular}{|l|c|c|}
\hline \multirow{2}{*}{\multicolumn{1}{|c|}{ Fonte }} & \multicolumn{2}{c|}{ Tipo de abordagem } \\
\cline { 2 - 3 } & Positiva & Negativa \\
\hline Autoridade & 84 & 19 \\
\hline Especialista & 11 & 16 \\
\hline Protagonista & 7 & 19 \\
\hline Usuário & 2 & 5 \\
\hline Empresário & 9 & 1 \\
\hline Total & 113 & 60 \\
\hline
\end{tabular}

Um dos princípios do jornalismo é a apuração rigorosa dos fatos sem que o jornalista emita opinião pessoal acerca do assunto. Muitas vezes confundida com análise, o jornalista tende a opinar quando se sente em condições para fazê-lo - prática que divide muitos profissionais e estudiosos da área. Para evitar a emissão de opinião, o jornalista recorre ao criticado 'jornalismo declaratório', ou seja, sustentado nas aspas ou paráfrases das fontes de informação. Preocupados em revelar mais de uma verdade - outro princípio do jornalismo, os profissionais da imprensa pautam, majoritariamente, mais de uma fonte de informação para, assim, mostrar os dois lados da notícia. Para alguns críticos, o problema continua e, pior, o jornalista, ao cobrir mais de uma fonte para debater o assunto, pode, voluntária ou involuntariamente, repassar ao leitor a responsabilidade de tomar a decisão acerca do que as fontes estão discutindo.

Um caso clássico na imprensa brasileira foi quando os jornais cobriram a nacionalização dos hidrocarbonetos na Bolívia. Alguns especialistas ouvidos pelos jornais diziam que iria faltar gás, enquanto outros diziam que isso não ocorreria. Havia ainda a terceira fonte que dizia que isso poderia ou não acontecer.

Em situações como essa cabe ao jornalista recorre à análise dos fatos, que não é sinônimo de opinião. $\mathrm{Na}$ análise, o jornalista recorre a alguns recursos como: contextualização, analogia e resgate histórico. 
No caso específico desta pesquisa, levantamos e exemplificamos com trechos das matérias coletadas como ocorreram as abordagens positiva e negativa nas 172 reportagens analisadas neste trabalho. Os gráficos 4 e 5 apresentam os principais pontos citados pelas fontes de informação que caracterizaram os discursos como sendo positivos e negativos, respectivamente.

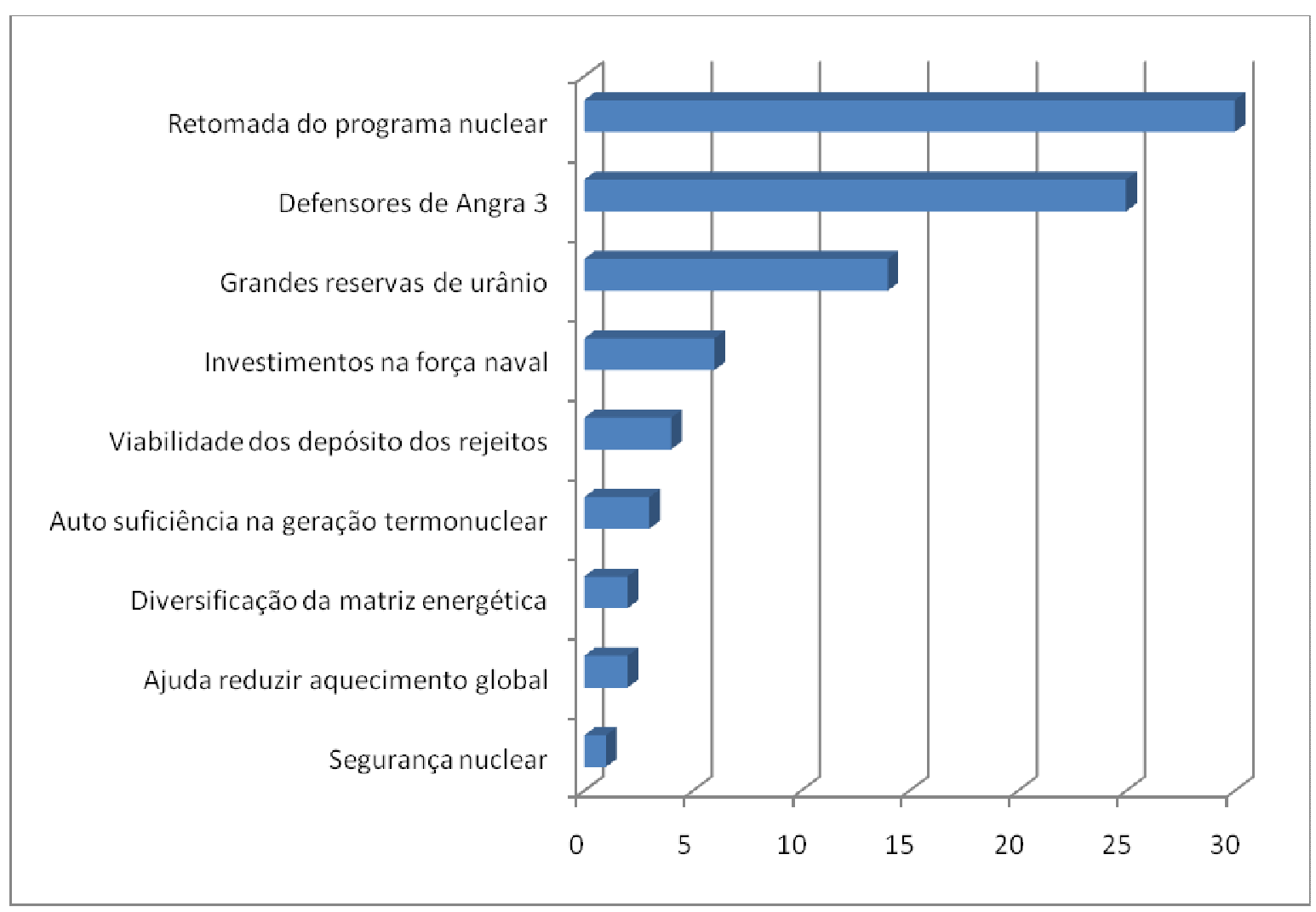

Gráfico 4 - Frequência dos principais pontos citados na caracterização das abordagens positivas 


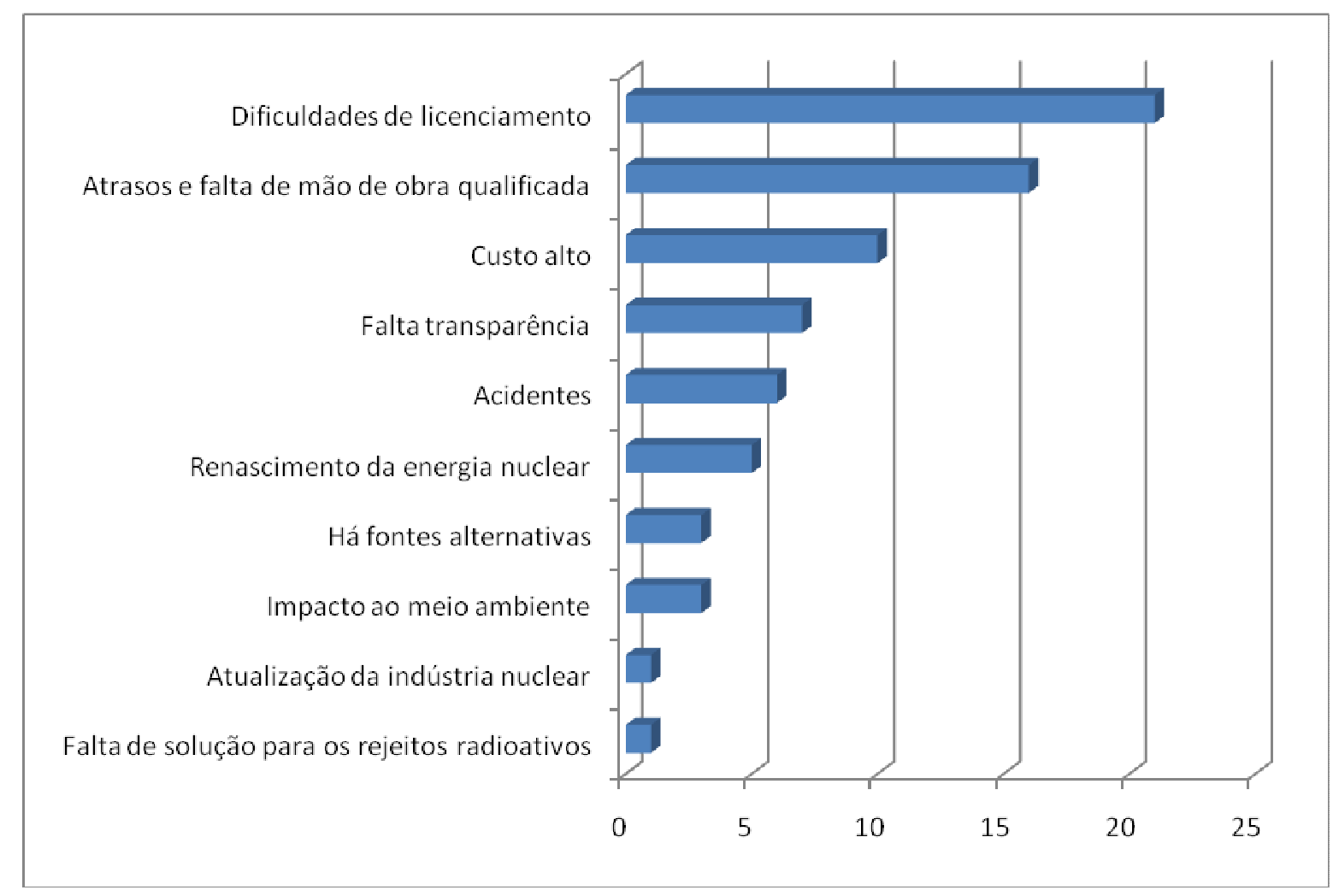

Gráfico 5 - Frequência dos principais pontos citados na caracterização das abordagens negativas

A abordagem positiva se fez presente em 85 matérias, focando nove itens como os principais pontos positivos da energia nuclear. Os três itens de maior importância referiram-se aos benefícios da retomada de programas nucleares no Brasil e em outros países, à construção de Angra 3 e outras usinas, e às grandes reservas nacionais de urânio, citados respectivamente em $35 \%, 29 \%$ e $16 \%$ das matérias.

A abordagem negativa se fez presente em 44 matérias, focando dez itens como os principais pontos negativos da energia nuclear. Os três itens de maior importância referiram-se às dificuldades de licenciamento de Angra 3 e ações contra a sua construção, evidências envolvendo atrasos e interrupções do programa nuclear brasileiro, e ao alto custos da tecnologia nuclear, citados respectivamente em $48 \%, 36 \%$ e $23 \%$ das matérias. É interessante salientar que a problemática dos rejeitos radioativos, normalmente apontada como um dos fatores determinantes da não aceitação da energia nuclear, apareceu citada somente em $2 \%$ das matérias negativas (e em $5 \%$ das matérias positivas). 


\subsection{Hegemonia das Fontes}

A frequiência de cada fonte de informação, quer dizer, a repetição com que aparece uma dada fonte revela a sua hegemonia.

O uso da palavra hegemonia, no entanto, é utilizado no sentido de dominação como predominância. No contexto da análise das fontes, quanto maior a predominância de uma fonte, mais se consegue identificar o caráter ideológico do discurso da mesma. Muitas fontes de informação são repetidas e tornam-se, como usado no jargão jornalístico, viciadas. Essas fontes viciadas rapidamente são transformadas em hegemônicas.

\subsection{O Discurso Hegemônico}

As expressões apresentadas pelos atores sociais puderam ser divididas basicamente em cinco grupos: os cientistas a favor da energia nuclear, os cientistas contra a tecnologia, os ambientalistas, as autoridades a favor da tecnologia e as autoridades contra a tecnologia; as expressões mais utilizadas estão apresentadas na Tabela 10. 
Tabela 10 - O discurso hegemônico

\begin{tabular}{|c|c|}
\hline Ator & Expressões descritas com freqüência nas reportagens \\
\hline $\begin{array}{l}\text { Cientistas a favor da energia } \\
\text { nuclear }\end{array}$ & $\begin{array}{l}\text { "usinas nucleares não queimam combustíveis fósseis", } \\
\text { "respirar o ar poluído de grandes cidades como SP e } \\
\text { Londres pode ser mais perigoso para a saúde do que } \\
\text { ser exposto a altos níveis de radiação", "somente a } \\
\text { energia nuclear é capaz de praticamente substituir os } \\
\text { modelos existentes", "energia nuclear é a melhor } \\
\text { opção" }\end{array}$ \\
\hline Autoridades a favor da tecnologia & $\begin{array}{l}\text { "somos detentores da sexta maior reserva de urânio do } \\
\text { mundo", "o país poderá entrar definitivamente na era } \\
\text { nuclear", "não dá para tocar o país apenas com energia } \\
\text { eólica e solar", "o país se prepara para dominar } \\
\text { inteiramente o ciclo de produção de urânio", "temos } \\
\text { profissionais para executar as atividades da cadeia de } \\
\text { produção necessária para o uso pacífico da energia } \\
\text { nuclear", "de incluir com coragem a energia nuclear } \\
\text { como parte importante de nossa matriz energética", } \\
\text { "Brasil tem urânio para } 80 \text { anos" }\end{array}$ \\
\hline Cientistas contra a energia nuclear & $\begin{array}{l}\text { "o Brasil não precisa investir numa energia cara como } \\
\text { a nuclear", "o nosso problema é a falta de energia, mas } \\
\text { temos outras alternativas", "a ampliação do parque } \\
\text { gerador nuclear é uma desculpa para o Brasil investir } \\
\text { em enriquecimento de urânio para abastecer o } \\
\text { mercado mundial" }\end{array}$ \\
\hline Ambientalistas & $\begin{array}{l}\text { "o que fazer com o lixo nuclear?", "dezenas de } \\
\text { reatores de energia nuclear ao redor do mundo podem } \\
\text { ser ameaçados pelo aumento do nível do mar","opção } \\
\text { pela expansão da energia nuclear é burra", "estão } \\
\text { usando maquiagem verde para tentar viabilizar uma } \\
\text { energia mais cara e desnecessária", "há outros } \\
\text { recursos com preços competitivos ou até mais baratos } \\
\text { que a energia nuclear" }\end{array}$ \\
\hline Autoridades contra a tecnologia & $\begin{array}{l}\text { "Brasil corre o risco de ingressar no clube da sujeira", } \\
\text { "o Brasil precisa gerar energia com sustentabilidade } \\
\text { ambiental nas obras", "o meio ambiente é contra a } \\
\text { construção nuclear de Angra 3", "seria trocar um } \\
\text { câncer por outro", "a energia nuclear não é prioritária } \\
\text { para o país", "a magnitude de um acidente nuclear é } \\
\text { muito grande" }\end{array}$ \\
\hline
\end{tabular}




\section{5 - CONCLUSÕES}

Deste trabalho pode-se concluir que:

- Há uma predominância de reportagens positivas sobre a energia nuclear na mídia impressa, lembrando que esse fato se deve ao maior número de autoridades consultadas como fonte de informação.

- As fontes de informação claramente mais tendenciosas são as representadas pelas ONGs, no aspecto negativo, e pelas autoridades e empresários, no aspecto positivo.

- A maioria dos veículos de comunicação rastreados mesclaram reportagens positivas e negativas sobre o tema.

- Há evidência de discurso hegemônico por parte das fontes oficiais.

- A abordagem positiva está predominantemente relacionada à retomada do progrma nuclear brasileiro, à necessidade de construção de Angra 3 e da auto-suficiência nas reservas de urânio.

- A abordagem negativa está predominantemente relacionada á dificuldade de licenciamento, atrasos e falta de mão de obra qualificada e aos altos custos da tecnologia nuclear. 


\section{REFERÊNCIAS BIBLIOGRÁFICAS}

ADAMS, J. Risk London, Routledge, 228p. 1995.

AGRAWALA,S. Explaning the evolution of the IPCC Studiere and Process. ENRP Discussion Paper E-97-05 Kennedy School of Government, Havard University, 1997.

ARBEX, M. A avaliação dos efeitos do material particulado proveniente da queima de plantação de cana-de-açúcar sobre morbidade respiratória na população de AraraquaraSP. São Paulo, 2001.

BALANÇO ENERGÉTICO NACIONAL 2007: Ano base 2006: Resultados Preliminares / Ministério de Minas e Energia. Empresa de Pesquisa Energética. - Rio de Janeiro: EPE, 2007.

BALANÇO ENERGÉTICO NACIONAL 2008: Ano base 2007: Resultados Preliminares / Ministério de Minas e Energia. Empresa de Pesquisa Energética. - Rio de Janeiro: EPE, 2008.

BACHETTA, V.L. Tese (doutorado) Faculdade de Medicina da Universidade de São Paulo Perfil del periodista ambiental, 2000. Artigo disponível em: http://www.saladeprensa.org/atr340.htm Acessado em: 15/09/2007.

BECK, U. Risk society. London: SAGE Publications, 1992.

BECK, U. La sociedad del riesgo global. Madrid: Siglo XXI de España, 2006.

BELMONTE, R. V, Jornalismo ambiental: histórias e compromissos. Entrevista para a revista Comunicação em Agrobusiness e Meio Ambiente, Volume 1, Número 1, Dezembro de 2004.

BELMONTE, R. V, Jornalismo Ambiental - Evolução e Perspectivas (1997). Artigo disponível em www.rvb.jor.br. Acessado em 12/06/2007.

BERLO D.K. O processo da Comunicação - Introdução à Teoria e à Prática. São Paulo: Martins Fontes, 1999.

BERNSTEIN, P. L. Desafio aos deuses. A fascinante história do risco. $3^{\text {a }}$ Ed. Rio de Janeiro: Campus, 1997.

BONDI, H. Risk in perspective. In: COOPER, M. (ed). Risk: man-made hazards to man.

BORD, R. e O'CONNOR, R. E. Risk communication, knowledge, and attitudes: explaining reactions to a technology perceived as risky. Risk Analysis, v.20, p.499506, 1990.

BPAMACO World Energy 1999. Statistical Review of World energy.

BRASIL NUCLEAR. Angra 3 e a retomada do Programa Nuclear Brasileiro. Rio de Janeiro: Vera Dantas, n. 13. jul. 2007. 
BREHMER, B. The psychology of risk. In: SINGLETON, W.T. e HOVDEN, J. (Eds). Risk ans decisions. Chichester: John Wiley and Sons Ltd., 1987.p.25-39.

BUENO, W. da C. (1984) Jornalismo científico no Brasil: os compromissos de uma prática independente. São Paulo: Tese de doutoramento apresentada à Escola de Comunicação e Artes da Universidade de São Paulo.

BUENO, W. da C. (2007) Comunicação ambiental. São Paulo, Editora Contexto.

BUENO, W. da C. (2003) O jornalismo científico e o despertar de vocações. Disponível em: www.jornalismocientifico.com.br/artigowilbuenojcdespertarvocacoes.htm. Acesso em $25 / 08 / 07$.

BUENO, W. da C. Jornalismo científico: teoria e prática, os novos desafios do jornalismo científico. Artigo disponível em:

http://www.jornalismocientifico.com.br/jornalismocientifico/artigos/jornalismo_cientifi co/artigo9.php. Acessado em: 17/08/2007.

CALDAS, G. Revista Fapesp Pesquisa, dezembro 2000, nº 60, p.8.

CANDIA, V. Ambientalismo sem extremismo, 2002. Artigo disponível em: amda.org.br/assets/files/ambientalismo.doc. Acessado em 10/08/2007.

CARNEIRO, A; MAI, L.A; MAPRELIAN, E.; SADUNDJIAN, G. Energia e desenvolvimento. In: Disciplina TNR 5768. São Paulo, IPEN, 2007.

CARPENTER, R.A. Risk Assessment. In: VANCLAY, F., BRONSTEIN, D. A. Environmental and social impact assessment. New York: JohnWiley E Sons,1995. Cap 9, p.193-219.

CAUBET , Christian Guy. O escopo do risco no mundo real e no mundo jurídico. In: VARELLA, Marcelo Dias (org) Governo dos Riscos. Brasília: Pallotti, 2005.

CETESB, Termo de referência para a elaboração de estudos de Análise de Riscos, São Paulo, Brasil.

COGLIANO, V. J. Plausible upper bounds: are their sums plausible? Risk Analysis, 17 (1), 1997.

COOPER, M. (ed). Risk: man-made hazards to man. Oxford, Clarendon Press, 1985.

COVELLO, V.T (ed). Environmental impact assessment, technology assessment and risk analysis: contributions from the psychological and decision sciences. New York, 1985.

COVELlO V.T. et AL. Risk Comunication, Risk Statistics and Risk Comparisons.

CRESPO S. E LEITÃO P. O que o brasileiro pensa da ecologia. Rio de Janeiro. MAST, CNPq, 1993. 
DAKE, K. \& WILDAVSKY, A. Individual diferences in risk perception and risk-taking preferences. In: GARRICK, B. J. e GEKLER, W.C. The analysis, communication and perception of risk. New York: Plenum Press, 1991.

DE FLEUR, M.L. Teorias da comunicação de massa. 2a . Rio de Janeiro: Zahar, 1976.

De FLEUR, M.L; BALL ROKEACH, S. A sociedade de massa e a teoria da bala mágica. In: Teorias de comunicação de massa. Rio de Janeiro, Zahar, 1968.

DELLA ROCCA, F. F. A percepção de risco como subsídio para processos de gerenciamento ambiental. Tese (Doutorado), Instituto de Pesquisas Energéticas e Nucleares - USP, São Paulo. 2002.

DEMAJOROVIC, Jaques. Sociedade de risco e responsabilidade socioambiental. São Paulo: SENAC , 2003.

DESTÁCIO, M.C. (2002) Jornalismo científico e divulgação científica. In: Kreinz, G \& Pavan, C. (orgs.). Ética e divulgação científica: os desafios do novo século. São Paulo: NCR da ECA-USP.

DIAZ BORDENAVE J.E. Além dos meios e mensagens: introdução à comunicação como processo, tecnologia, sistema e ciência. 2a . Petropólis: Vozes, 1986.

DIXON B. Para que serve a ciência? 2a . São Paulo: Cia. Editora Nacional, 1976.

DODERLEIN, J.M. Risk and decisions: introduction. In: Singleton WT, Hovden J. Risk and decisions. Chichester. John Wiley \& Sons, 1987.p.1-8.

DOUGLAS, M. Risk as a forensic resource. DEADALUS: J. Am. Acad. Arts Sci, v.4 (fall), p. 1-16, 1990.

DROTTZ-SJÖBERG, B.; Sjörberg, L. Risk percepction and worries after the Chernobyl accident. Journal of Environmental Psycology, 10, 1990, pp.135-149.

ENERSUL. Energias do Brasil. História da Energia. Disponível em: http://www.enersul.com.br/aescelsa/pesquisa-escolar/historia.asp Acesso em 03 mar 2008.

EMERY E. Introdução à comunicação de massa. São Paulo, Atlas, 1973.

FAYARD, P. A comunicação científica pública. Liyon: Ch. Soc., 1988.

FISCHHOFF, B. Acceptable risk: a conceptual proposal. Risk: Health, Safety \& Environment, v. 1, p. 1-28, 1994.

FISCHHOFF, B.; SLOVIC, P.; LICHTENSTEIN, S.; READ, S. e COMBS, B. How safe is safe enough? A psychometric study of attitudes towards technological risks and benefits. Politic Sciences, v.9, p:127-152, 1978. 
FISCHHOFF, B.; WATSON, S. R. e HOPE, C. Defining risk. Policy Sciences, v. 17, p.123-139, 1984.

Folha de S. Paulo. (2001) Manual de Redação.São Paulo: PubliFolha. GENRO FILHO, Adelmo. O Segredo da Pirâmide: para uma Teoria Marxista do Jornalismo. Porto Alegre: Tchê, 1987.

GARRICK, B. J. The analysis, communication, and perception of risk. New York, 1991.

GIDDENS, A. As conseqüências da modernidade. São Paulo: Editora UNESP, 1991.

GIROTTI, C. A. Estado nuclear no Brasil. São Paulo: Editora Brasiliense, 1984.

GONÇALVES, N.L. (1998) Divulgação científica. In: Kreinz, G. \& Pavan, C. (orgs.).A espiral em busca do infinito: ensaios sobre o divulgador científico José Reis. São Paulo: NJR da ECA-USP.

GRINBERG, M.S. (org.) A comunicação alternativa na América Latina. Petrópolis: Vozes, 1987.

GUTZ, I. G. R.. Mudanças globais e desenvolvimento sustentável: desafios para a ciência. São Paulo, S.P., Instituto de Estudos Avançados, série Ciências Ambientais, 20. Nov, 1994.

HANSSON, S.O. Dimensions of risk. Risk Analysis, 9 (1), 1989.

HOUGHTON, J. T et al. IPCC First Assessment Report. Cambridge University Press, UK 1990.

HOUGHTON, J. T et al. IPCC Second Assessment Report. Climate change. Cambridge University Press, UK 1995.

IGAMI, M. P .Z. Guia para elaboração de dissertação e teses. São Paulo: IPEN, 2002.

INTERNATIONAL ATOMIC ENERGY AGENCY (IAEA). Radiation and society: comprehending radiation risk: proceedings. Paris, 24-28 out, 1994. Viena, 1994 v. I.

JENNI, K.E. Attributes for risk evaluation. Doctor dissertation, Carnegie Mellon University, 1997.

JOHN, L. O que estamos fazendo com os nossos oceanos? (1997). Artigo disponível em: www.cprh.pe.gov.br/ctudo-secoes-sub.asp?idsecao=293 Acessado em 10/08/2007.

KREINZ, G \& PAVAN, C. (orgs.). Ética e divulgação científica: os desafios do novo século. São Paulo: NCR da ECA-USP.

KOLLURU, R.; BARTELL, S.; PITBLADO, R.; STRICOFF, S. Risk assessment and managenment handbook. New York, N.Y., McGraw-Hill, 1994. 
KOLLURU, Rao V.. Environmental strategies handbook. New York, N.Y., McGrawHill, 1994.

KUNCZIK, M., Conceitos de Jornalismo - Norte e Sul. São Paulo: Edusp, 2001.

LIMA, L.C. (org.). Teoria da cultura de massa. $3^{\mathrm{a}}$. Rio de Janeiro: Paz e Terra, 1982.

LIMA \& SILVA. Dicionário brasileiro de Ciências Ambientais. Rio de Janeiro, RJ 1999.

LINDELL, B. The risk philosophy of radiation protection. In: Norwegian Radiation. Protection Authority. Radiation risk, risk perception and social constructions: proceedings of an workshop on ... realizado em Oslo, Norway, 19-20 out, 1995. Brussels, 1996.pp.157-164.

LOPES, D.F. at al. A evolução do jornalismo em São Paulo. São Paulo: Edicon, 1998.

LUPTON, D. Risk as moral danger:t he social and political functions of risk discourse in public health. In: International Journal of Health Services. Baywood Publishing Co. Volume 23, p. 425-435, 1993.

MARCONDES F. C. O capital da notícia - jornalismo como produção social da segunda natureza. São Paulo: Ática, 1989.

MATTELART A. A globalização da comunicação. Bauru, SP: EDUSC, 1988.

MEDINA, C. A. Profissão jornalista: responsabilidade social. Rio de Janeiro: Ed. Forense-Universitária, 1982.

MELO, José Marques de. Comunicação, Opinião, Desenvolvimento, São Paulo, Ed Vozes, 1971.

MELO, José Marques de. Paradigmas da Escola Latino-Americana de Comunicação. Comunicação \& Sociedade, Universid. Fed. de Goiás -, v. 2, n. 2, 2000.

MIÉGE B. O Pensamento Comunicacional. Petrópolis, RJ, 2000.

MOURA, L. A. A.; Qualidade e gestão ambiental. São Paulo: Editora Juarez de Oliveira, 2002.

NARDOCCI, A.C. Risco como instrumento de gestão ambiental. 2000, Tese (Doutorado) - Faculdade de Saúde Pública da Universidade de São Paulo, SP.

NATIONAL SAFETY COUNCIL (NSC). Regulating risk: the science and politics of risk. Washington, D.C., International Life Sciences Institute, 1993.

NELSON P. Dez dicas práticas para reportagens sobre o meio ambiente. Virgínia. Center for Foreign Journalists, 1994.

NEOTTI C. A nova ordem da informação e da comunicação. Petrópolis: Vozes 1986. 
NIELSEN, T.H.. Risks - in technology, society and the mind. Radiation Protection Dosimetry, 68(03), 1996, pp.181-4.

NRC National Research Council - Risk Assessment in the Federal Government: Managing the Process National Academy Press, Washington, D.C.

NYLAND, L.G.. Risk perception in Brazil and Sweden. Risk Research Reports, Report 15. Center for Research, Stockholm.nov, 1993.

Oliveira, F. (2002) Jornalismo científico. São Paulo: Contexto.

PENTEADO J.R.W. A técnica da comunicação humana. Livraria Pioneira Editora. $8^{\text {a }}$. São Paulo, 1982.

PERUZZO, C.M.K. Comunicação nos movimentos populares - a participação na construção da cidadania. Petrópolis: Vozes, 1998.

PETTERSON, J. PERCEPTION VS. Reality of radiological impact: the Goiania model. Nuclear News, nov, 1988.

PIERANTI, A. P. Para a população de Angra, usinas trazem benefícios. Brasil Nuclear, n. 21 p. $24,2000$.

PONTING, C. A green history of the world. Penguim Books. Nova York, EUA, 1991.

PRICE, D. Energia e Evolução Humana. Resistir.info. Disponível em: http://resistir.info/energia/energia_e_evolução_humana.html .Acesso em 4 de maio 2008.

RAMOS, L. F. A. O discurso ambiental na comunicação de massa: um estudo da conferencia das nações unidas sobre o meio ambiente e desenvolvimento, São Paulo, 1994.

RAYNER S. Cultural theory and risk analysis. In: Krinsky S. Golding D, editors. Social theories of risk. London: Praeger, 1992.p.53-79.

REDCLIFT M; Sage, C. (eds). Strategies for sustainable development. New York, J. Wiley Sons, 1994.

REIS, J. Divulgação Científica. Revista Espiral, More Majorum, $\mathrm{n}^{\circ} 27$ (abr - mai - jun 2006). Artigo disponível em:http://www.eca.usp.br/nucleos/njr/espiral/more27b.htm. Acessado em: 12/10/2007.

ROMANZINI G. et. al. Comunicação e controle social. Petrópolis, RJ, 1991.

RUBIM, A. A. C. at al. Produção e recepção dos sentidos midiáticos. Petrópolis: Vozes, 1998. 
SANDMAN, P. Definitions of risk. In: International Atomic Energy Agency. Radiation and society: comprehending radiation risk. Washington, D.C., International Life Sciences Institute, 1993, pp3-6.

SANTOS, S. L. \& EDWARDS S. Comparaive Study of Risk Assessment and Risk Communication Pratices In: Western Europe; a report prepared for the German Marshall Fundo of the United States, May, 1990.

SANTOS, S. L. \& McCallum DB. Public Knowledge and Attitudes of Chemical Risks in Six Communities. A Report of a Followup Survey, Columbia University Center for Risk Communication, September, 1993.

SHADER-FRECHETE K. Risks and ethics. In: International Conference on Radiation and Society:: Comprehendig Radiation Risk. Paris (France). 21-28 oct. 1994. Editor IAEA. July 1994; Proceding Series p. 167-182.

SJÖBERG, L.; DROTTZ-SJÖBERG, B. Risk perception. In: International Atomic Energy Agency. Radiation and society: comprehending radiation risk: proceedings of an workshop on...realizado em Paris, 24-28 out, 1994. Viena, 1994. V. I pp.29-60.

SJÖRBERG L. Perceived Risk vs. Demand for risk reduction. Stockholm: Center for Risk Research, 1992. Report n 18.

SLOVIC, P. Perception of risk from radiation. In: Norwegian Radiation Protection Authority. Radiation risk, risk perception and social constructions: proceedings of an workshop on .. realizado Norway, 19-20 out, 1995. Brussels, 1996, pp.165-180.

SLOVIC, P. Perceived Risk, Trust and Democracy. Risk Analysis, Vol. 13, n 6, 1993.

SLOVIC, P. Perception of risk:reflections on the psychometric paradigm. In: Krinsky S, Golding, D, editors. Social theories of risk. London: Praeger, 1992. P. 117-52.

SLOVIC, P. Percpetion of risk. Science, 236, 1987, pp.280-5.

SOCIETY FOR RISK ANALYSIS. Glossary. Disp. em: http: //www.sra.org. acesso $12 / 04 / 08$.

SOUZA, M. P. Instrumentos de gestão ambiental: fundamentos e prática. S. Carlos 112p. Ed. Riani Costa, 2000.

STALLEN, P. J.M., GEERTS, R., VRIJILING, H.K..Three conceptions of quantified societal risk. Risk Analysis, 16(5), 1996.

STARR, C. Social benefit versus technological risk. Science, v.165, p.1232-1238. 1969.

STERN P. \& F INEBERG, H. Understanding Risk - informing decision in a democratic society. Washington: National Academy Press, 1996.

THOMPSON, J. B. A mídia e a modernidade - uma teoria social da mídia. Petrópolis: Vozes, 1998. 
U S ENVIRONMENTAL PROTECTION AGENCY (USEPA). Guidelines for ecological risk assessment: final report. Washigton, DC: USEPA, 1998 (EPA/630/R-95/002F).

VICTOR da SILVA, C. Comunicação de Riscos Ambientais - Uma ferramenta para a tomadade decisão. Estudo de Caso: projeto de incineração de resíduos sólidos domiciliares para a cidade de São Paulo. São Paulo, 2001, Tese (Doutorado) Faculdade de Saúde Pública da Universidade de São Paulo.

WILDAVSKY, D. M. E DAKE, K. Theories of risk perception: who fears what and why? Journal of the American Academy of Arts and Sciences, v.4, p.41-60, 1990.

WILliS, J. \& OKUNADE A. A. Reporting on Risk - The Practice and Ethics of Health and Safety Communicatios. Westport: Praeger Publishers, 1997. 
Anexo: cópia das reportagens analisadas 